\title{
Age, geochemical characteristics and petrogenesis of Cenozoic intraplate alkaline volcanic rocks in the Bafang region, West Cameroon
}

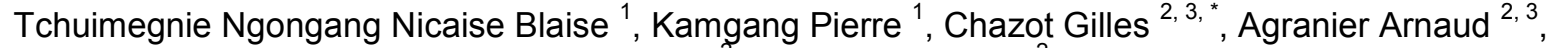 \\ Bellon Hervé $^{2}$, Nonnotte Philippe ${ }^{2}$
}

\footnotetext{
${ }^{1}$ Département des Sciences de la Terre, Faculté des Sciences, Université de Yaoundé I, B.P. 812, Yaoundé, Cameroun

${ }^{2}$ Université de Brest (UBO), UMR 6538, Domaines Océaniques, Institut Universitaire Européen de la Mer, place Copernic, 29280 Plouzané, France
}

Corresponding author : Gilles Chazot, email address : Gilles.Chazot@univ-brest.fr

\begin{abstract}
:
The origin of the volcanism in the Cameroon Volcanic Line and the nature of its mantle sources are still highly controversial. We present major and trace element compositions as well as $\mathrm{Sr}-\mathrm{Nd}$ - $\mathrm{Pb}-\mathrm{Hf}$ isotopic results on mafic and intermediate lavas from the Bafang area in the central part of the Cameroon Volcanic Line. The lavas range from basanites and basalts to hawaiites and mugearites with an alkaline affinity and were emplaced between 10 and $6 \mathrm{Ma}$ ago. The evolution from basalts and basanites to more differentiated rocks involved fractionation of olivine, clinopyroxene and Fe-Ti oxides, but the isotopic compositions show that crustal contamination processes affected some magmas during their ascent in the crust. Basalts and basanites originated from a garnet-bearing mantle source and their differences are mostly due to variable degrees of partial melting. The isotopic composition of the uncontaminated samples imply the participation of three distinct mantle components, the depleted MORB mantle (not dominant), an enriched component and a $\mathrm{Pb}$ radiogenic component similar to the source of the Mount Cameroon. Combined with previously published isotopic data from the Cameroon Volcanic Line, our new results indicate that the source of the volcanism mostly reside in the lithospheric mantle and is different from what can be expected from the melting of a mantle accreted from or modified during the emplacement of the St Helena mantle plume.
\end{abstract}




\section{Highlights}

Basalts, basanites, hawaiites and mugearites of alkaline affinity are present in the Bafang area. They formed from 10 to $6 \mathrm{Ma}$ ago. Some lavas are contaminated by the crust as shown by their modified isotopic composition. The source of these magmas is in the lithospheric mantle and is different than the source of the St Helena mantle plume.

Keywords : Cameroon Volcanic Line, Geochemistry, Magmatism, Mantle source

\section{Introduction}

The role of the lithospheric mantle in the petrogenesis of continental basalts is difficult to evaluate, as its nature and composition are known to be highly variable, and sometime not easily distinguishable from deeper mantle sources. The genesis of intraplate alkaline basalts remains therefore a matter of considerable debate. This volcanism is the subject of many geochemical investigations on large continental flood basalt (CFB) provinces as well as smaller volcanic fields (Jung and Masberg, 1998, Zou et al., 2000 and Barry et al., 2003). The contamination of the asthenospheric mantle by lithospheric material, recognized in the geochemistry of some CFB, is classically accounted for by lithospheric delamination (e.g. Mc-Kenzie and O'Nions, 1995) or ancient subduction processes (e.g. Hofmann, 1988). However, there is increasing evidence that melts originated in the asthenosphere can interact with the lithospheric mantle en route to the surface (Chazot et al., 1996, Wulff-Pedersen et al., 1996 and Class and Goldstein, 1997) and lead to these intermediate geochemical signatures.

The Cameroon Volcanic Line (CVL) appears as a SW-NE straight line (Fig. 1) displaying a "swell and basin" geometry. It is a chain of 12 Cenozoic and Quaternary 
volcanic massifs covering approximately $1600 \mathrm{~km}$ from Annobon Island in the Gulf of Guinea to Lake Chad, and active from Eocene to the Present (Déruelle et al., 2007 and references therein). The chain can be splitted into a continental and an oceanic part, which is a unique feature for Africa and even for the world (Déruelle et al., 1991, 2007). In more details three distinct zones can be identified : 1- the oceanic sector (Annobon, Sao Tome and Principe), 2- the continent/ocean boundary (c.o.b.: Bioko, Etinde and Mt. Cameroon) and 3the purely continental sector. This last part of the chain is constituted of tens to a hundred of kilometers-scale volcanic massifs including Manengouba, Bambouto, Bamenda and Oku mountains as shown on Figure 1. Early on, Fitton and Dunlop (1985) recognized geochemical similarities between trace elements and $\mathrm{Sr}$ isotopes of basalts from both oceanic and continental sectors. Based on these data, they suggested that these melts were extracted from sub-lithospheric depths without interaction with the overlying lithosphere. Later on, Halliday et al. $(1988,1990)$ reported anomalously high ${ }^{206} \mathrm{~Pb} /{ }^{204} \mathrm{~Pb}$ ratios (up to 20.5) for lavas from the c.o.b., with lower ${ }^{206} \mathrm{~Pb} /{ }^{204} \mathrm{~Pb}$ ratios $(19-20)$ for volcanic rocks from the oceanic and continental sector. These results, combined to $\mathrm{Sr}, \mathrm{Nd}$ and $\mathrm{O}$ isotopes, suggested that the high ${ }^{206} \mathrm{~Pb} /{ }^{204} \mathrm{~Pb}$ signatures are due to the recent remelting of the St. Helena fossil plume head within the lithospheric mantle, after that $\mathrm{U} / \mathrm{Pb}$ fractionation occurred during melt migrations as the plume head was cooling down about $125 \mathrm{Myr}$ ago. As a consequence, in this model, the $\mathrm{Pb}$ isotope anomaly observed in volcanic rocks from the CVL, cannot be derived from metasomatized lithosphere. Moreover, this fossil plume model is consistent with a recent helium isotopes study of Aka et al. (2004), who reported MORB-like ${ }^{3} \mathrm{He} /{ }^{4} \mathrm{He}$ ratios (from 7.85 to $8.31 \mathrm{Ra}$, where $\mathrm{Ra}$ is the atmospheric ratio) for melts from both oceanic and continental sectors associated with HIMU-OIB-like He ratios for the c.o.b (from 4 to $6 \mathrm{Ra}$ ). In this paper, we present new $\mathrm{K}-\mathrm{Ar}$ ages, major and trace element concentrations and $\mathrm{Sr}-\mathrm{Nd}-\mathrm{Pb}$ - 
Hf isotopes of mafic lavas from Bafang in western Cameroon in order to further investigate magma generation in this area.

\section{2- Geological setting}

The Bafang area is located within the Western Cameroon highlands (Bambouto, Bamenda and Oku Mountains) in the central part of the Cameroon Volcanic Line (Fig. 2). It lies between the Manengouba mountain in the South-West and the Noun Plain in the North. The studied area is geographically bounded by the latitudes $05^{\circ} 4^{\prime} 21^{\prime \prime}$ and $05^{\circ} 13^{\prime} 38^{\prime \prime}$ ' North and the longitudes $10^{\circ} 8^{\prime} 17^{\prime \prime}$ and $10^{\circ} 19^{\prime} 38^{\prime \prime}$ East and represents a surface of about $500 \mathrm{~km}^{2}$. In this region, the Pan-African basement consists mainly of syntectonic granitoids (Dumort, 1968; Nguiessi et Vialette, 1994; Nguiessi et al., 1997; Nzolang et al., 2003). The lavas sampled in the Bafang area have mafic to intermediate composition, and no felsic rocks have been observed on the field. In this region, the vegetal cover is dense and the samples were therefore mostly recovered from artisanal quarries and small disseminated outcrops. Accordingly, no spatial continuity or stratigraphic relationship can be established between the samples.

\section{3- Analytical methods}

\section{1- K-Ar geochronology}

Potassium-argon ages were measured at the Université de Bretagne Occidentale, in Brest (France) on chips of whole rock lavas, 0.3 to $0.15 \mathrm{~mm}$ in size, that were prepared after crushing and subsequent sieving of the solid samples.

One aliquot of grains was powdered in an agate grinder for chemical attack of around $0.1 \mathrm{~g}$ of powder by $4 \mathrm{cc}$ of hydrofluoric acid, before its analysis of $\mathrm{K}$ content by AAS (Atomic Absorption Spectrometry). 
A second aliquot of grains was reserved for argon analysis. About $0.3 \mathrm{~g}$ to $0.8 \mathrm{~g}$ of grains were heated and fused under vacuum in a molybdenum crucible, using a high frequency generator. Released gases during this step were cleaned successively on three quartz traps containing titanium sponge when their temperature was decreasing from $800^{\circ} \mathrm{C}$ to the ambient one during 10 minutes; at the final step the remaining gas fraction was ultra-purified with an Al-Zr SAES getter.

Isotopic composition of argon and concentration of ${ }^{40} \mathrm{Ar}_{\mathrm{R}}$ were measured in a stainless steel mass spectrometer with a $180^{\circ}$ geometry. Isotopic dilution was realized with the fusion step, using for this process precise concentrations of ${ }^{38} \mathrm{Ar}$ buried as ions in aluminium targets (Bellon et al., 1981).

\section{2- Major and trace element analyses}

Whole-rock major elements were measured on the Horiba - Jobin-Yvon ${ }^{\circledR}$ Ultima 2 ICP-AES at the IUEM (European Institute for Marine Studies, Pôle de Spectrométrie Océan, Brest, France). The detailed description of the analytical procedure is given in Cotten et al. (1995). Major elements were determined from an $\mathrm{H}_{3} \mathrm{BO}_{3}$ solution, boron being used as internal standard for ICP-AES analysis. For major elements, relative standard deviation is $1 \%$ for $\mathrm{SiO}_{2}$ and $2 \%$ for the other major elements, except for low values $(<0.50 \mathrm{wt} . \%)$, for which the absolute standard deviation is \pm 0.01 wt. $\%$.

Trace element concentrations were measured with a Thermo Element2 HR-ICP-MS in Brest (France), after a repeated $\mathrm{HF}-\mathrm{HClO}_{4}$ digestion, and $\mathrm{HNO}_{3}$ dilutions (see $\mathrm{Li}$ and Lee, 2006 for details). The repeated analysis of the international standard BCR2 demonstrated an external reproducibility better than 5-10\% depending on the element and concentration.

\section{3- $\mathrm{Sr}-\mathrm{Nd}-\mathrm{Pb}-\mathrm{Hf}$ isotopic analyses}


$\mathrm{Pb}$ and $\mathrm{Hf}$ isotope compositions were obtained from single $\mathrm{HF}^{-\mathrm{HNO}_{3}}$ dissolutions of 500mg-1g of sample following the protocol described by Blichert-Toft et al. (2005). Pb and Hf isotopes were analysed using the Thermo Neptune MC-ICP-MS of Ifremer-Brest. $2 \sigma$ internal errors never exceeded the last significant digit $\left(1 \mathrm{E}^{-5}\right)$ in each analysis.

$\mathrm{Sr}-\mathrm{REE}$ dried fractions, previously collected at the beginning of $\mathrm{Pb}$ column separation, were dissolved and dried two times with $\mathrm{HNO}_{3}$ at $95^{\circ} \mathrm{C}$ until complete dryness. Dry samples were dissolved again in $\mathrm{HCl}$ prior to elution. Chemical separation for $\mathrm{Sr}$ and $\mathrm{REE}$ was performed on cationic DOWEX ${ }^{\circledR}$ AG50X8 200-400 mesh columns. Sr was kept and proceeded another time in the same column to efficiently separate $\mathrm{Sr}$ from $\mathrm{Rb}$ and $\mathrm{Ca}$. $\mathrm{Nd}$ was further eluted on LnSpec Eichrom resin. Isotopic measurements were performed on a Thermo Scientific Triton at the IUEM in Brest (France). Sr was run on a single W filament with Ta activator, while $\mathrm{Nd}$ was run on a $\mathrm{Re}$ double filament. International standards were run regularly to check our measurements: (1) Sr: NBS987, average value ${ }^{87} \mathrm{Sr} /{ }^{86} \mathrm{Sr}=0.710262 \pm 12$ $(2 \sigma, \mathrm{n}=10)$; (2) Nd: JNdi-1, average value ${ }^{143} \mathrm{Nd} /{ }^{144} \mathrm{Nd}=0.512106 \pm 14(2 \sigma, \mathrm{n}=6)$; La Jolla, average value ${ }^{143} \mathrm{Nd} /{ }^{144} \mathrm{Nd}=0.511848 \pm 12(2 \sigma, \mathrm{n}=3)$. Blanks were less than $340 \mathrm{pg}$ for $\mathrm{Sr}$ and $180 \mathrm{pg}$ for $\mathrm{Nd}$, and therefore considered negligible.

\section{4- Nomenclature and petrography}

\section{1- Nomenclature}

All the major oxides have been normalized to $100 \%$ on an anhydrous basis. Data are plotted on the total alkali vs. silica diagram (Le Bas et al., 1986) with subalkaline-alkaline dividing line of Irvine and Baragar (1971) for the purpose of classification (Fig. 3). According to this diagram, all the samples have alkaline affinity. Based on whole rock major element 
chemical compositions the Bafang samples range in composition from basanite (more than $10 \%$ normative olivine), basalt and hawaiite to mugearite. In the $\mathrm{Na}_{2} \mathrm{O}$ vs. $\mathrm{K}_{2} \mathrm{O}$ diagram of Middlemost (1975) shown in Figure 3, the Bafang mafic lavas plot mainly in the Na-series field $\left(\mathrm{Na}_{2} \mathrm{O} / \mathrm{K}_{2} \mathrm{O}=1.50-2.79\right)$, and are characterized by high alkalinity index $\left(\left(\mathrm{Na}_{2} \mathrm{O}+\mathrm{K}_{2} \mathrm{O}\right)-\right.$ $\left(0.37 * \mathrm{SiO}_{2}-14.43\right)$ from +1.49 to +5.15$)$.

\section{2- Petrography}

Basanites and basalts have a microlitic porphyritic texture. The groundmass is made of plagioclase, olivine, clinopyroxene and Fe-Ti oxides. They contain large olivine and clinopyroxene phenocrysts (up to $2 \mathrm{~mm}$ ) and some rare plagioclases. Some olivine crystals present evidences for iddingsitisation. Quartz xenocrysts with wavy extinction jacketed by clinopyroxenes corona, and alkali feldspar with disequilibrium texture occasionally occur in the basanites. Some samples contain green-core clinopyroxenes.

Hawaiites are subaphyric to porphyritic with a groundmass dominated by plagioclase microlites. Phenocrysts are mainly clinopyroxene and Fe-Ti oxides except in some samples where large plagioclases with concentric zoning (from 5 to $9 \mathrm{~mm}$ in length) are present.

Mugearites are microlitic with a groundmass made of plagioclase, olivine, clinopyroxene, and euhedral microcrystals of apatite. One sample contains micro-phenocrysts of clinopyroxene and plagioclase.

\section{Results}

Whole-rock major and trace element compositions are given in table 1.

\subsection{Major element geochemistry}

As no felsic rocks have been discovered on the field, our samples cover a moderate range in $\mathrm{SiO}_{2}$ composition (Fig. 4), ranging from 43 to 53 wt. \%, but a wider range of Mg-number 
$\left(\mathrm{Mg} \#=100 *(\mathrm{MgO} / 40.31) /\left(\left(\mathrm{MgO} / 40.31+\mathrm{Fe}_{2} \mathrm{O}_{3} * 0.8998 /(71.85 *(1-0.15))\right)\right.\right.$, assuming $\mathrm{FeOt}=\mathrm{Fe}_{2} \mathrm{O}_{3} \times 0.8998 \mathrm{Fe}_{2} \mathrm{O}_{3}$ ) ranging from 24 to 60.4. $\mathrm{Al}_{2} \mathrm{O}_{3}$ increases from 12.3

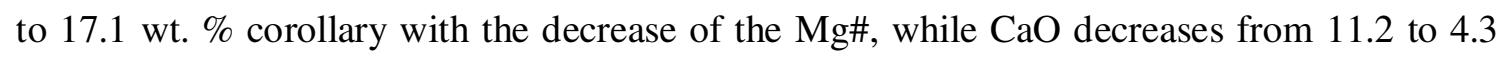
wt.\% and $\mathrm{Na}_{2} \mathrm{O}$ and $\mathrm{K}_{2} \mathrm{O}$ increases from 2.2 to 5.3 wt.\%, and from 1.2 to 2.5 wt.\%, respectively. As illustrated in figure 4, these major element trends are compatible with an evolution of the magmas through the fractionation of olivine, clinopyroxene and Fe-Ti oxides.

\subsection{Trace elements geochemistry}

The samples have highly variable compatible element contents. For example, $\mathrm{Cr}$ ranges from 1.6 to $515 \mathrm{ppm}$ and Ni from 1.1 to $261 \mathrm{ppm}$ (Fig. 4), and their content decreases with increasing $\mathrm{Mg \#}$, indicating that fractionation of olivine and clinopyroxene are the main factors controlling the compatible element abundances. $\mathrm{Ni}, \mathrm{Cr}$ and $\mathrm{Co}$ contents in the most mafic lavas are generally smaller than the values assumed for primary magmas (Ni: $300-400$ ppm; Cr: 300 - 500 ppm; Co: 50 - 70 ppm; e.g., Frey et al., 1978; Jung and Masberg, 1998), but are still high enough to indicate that for these samples the fractionation was limited.

The chondrite-normalized rare earth element (REE) patterns of Figure 5a reveal low degrees of melting, as all the samples are highly enriched in light REE relative to heavy REE $\left([\mathrm{La} / \mathrm{Yb}]_{\mathrm{N}}=11.92-20.14\right.$, where the subscript $\mathrm{N}$ means chondrite-normalized $)$. REE patterns of N-MORB, E-MORB of Sun and Mcdonough (1989) are also shown in Figure 5 for comparison. As revealed by Figure 5a, REE patterns of all samples are mostly above those of N-MORB and E-MORB and strongly resemble that of alkali Ocean Island Basalts (OIB) from St Helena, but with higher REE concentrations ([La] up to 180 times the concentration in chondrites), more akin to those of the Mount Cameroon volcanic rocks (Yokoyama et al., 2007). 
In Figure 5, all samples have positive europium anomalies $\left(\mathrm{Eu} / \mathrm{Eu}^{*}=1.00-1.29\right.$, where $\mathrm{Eu}$ is normalized $\mathrm{Eu}$ and $\mathrm{Eu}^{*}$ is $\mathrm{Eu}$ interpolated between normalized $\mathrm{Sm}$ and $\mathrm{Gd}$ : $\mathrm{Eu}^{*}=$ $\left.\left(\mathrm{Sm}_{\mathrm{N}} \mathrm{xNd} \mathrm{N}_{\mathrm{N}}\right)^{1 / 2}\right)$. Nevertheless, phenocrysts of plagioclase are almost absent from these rocks and thus, their accumulation cannot be responsible for this excess of Eu and this feature should probably be accounted for by a source effect. On a wider primitive-mantle normalized spiderdiagram of Figure 5b, Bafang rocks still resemble OIB from St. Helena, but with higher trace element concentrations, similarly to Mt. Cameroon (Yokoyama et al., 2007). However, samples from Bafang have some geochemical peculiarities: low Th and U concentrations and high $\mathrm{Ba}$ values. In some samples, mostly basalts and basanites, positive $\mathrm{Sr}$ anomalies can also be recognized.

\subsection{Geochronology}

Six samples have been dated by the K-Ar method. The Ar isotopic data and calculated ages for the samples are listed in table 2. Resulting ages are distributed between 10 and $6 \mathrm{Ma}$ and show three chronological stages of volcanic activity during the Upper Miocene: between 10.46 and $9.57 \pm 0.25 \mathrm{Ma}$ with the emplacement of basanites, at $8.47 \pm 0.26 \mathrm{Ma}$ and between 6.89 and $6.27 \pm 0.17 \mathrm{Ma}$, with the outpour of basalts and mugearites.

These data show that mafic volcanism exists in the Bafang area over a long period of time without any spatial evolution; they can be compared and agree with a few ages of volcanism in the neighboring sectors: $10.46 \pm 0.28 \mathrm{Ma}$ in the Noun Plain for Tchanda Boro volcano (Wotchoko et al., 2005); $9.37 \pm 0.05 \mathrm{Ma}$, a plateau age for a flow on the south-eastern border of Manengouba (Pouclet et al., 2014) 6.5 \pm 0.3 Ma (Nana, 1998) for Mont Bana, and 6.05 \pm 0.05 Ma for Bambouto Mountains (Youmen, 1994).

\section{4. $\mathrm{Sr}, \mathrm{Nd}, \mathrm{Pb}$ and $\mathrm{Hf}$ isotope geochemistry}


$\mathrm{Sr}, \mathrm{Nd}, \mathrm{Pb}, \mathrm{Hf}$ isotope analyses are provided in Table 3. Because of the relatively young ages of the samples, no age correction is necessary. ${ }^{87} \mathrm{Sr} /{ }^{86} \mathrm{Sr}$ ratios range from 0.70312 to 0.70417 , while ${ }^{143} \mathrm{Nd} /{ }^{144} \mathrm{Nd}$ ratios vary from 0.51281 to $0.51294,{ }^{206} \mathrm{~Pb} /{ }^{204} \mathrm{~Pb}$ from 19.037 to 20.072, ${ }^{207} \mathrm{~Pb} /{ }^{204} \mathrm{~Pb}$ from 15.540 to $15.666,{ }^{208} \mathrm{~Pb} /{ }^{204} \mathrm{~Pb}$ from 38.652 to 39.871 and ${ }^{176} \mathrm{Hf} /{ }^{177} \mathrm{Hf}$ from 0.28288 to 0.28294 .

Compared with both oceanic and the rest of the continental part of the CVL, Bafang volcanic rocks display a larger range of $\mathrm{Sr}$ isotopic compositions, with values higher than 0.7038 for two basalts, two hawaiites and one mugearite (Fig. 6a). As a whole, the trend defined by Bafang lavas is parallel to the trend defined by the Bamenda lavas (just North to this study area) (Kamgang et al., 2013), but with higher ${ }^{143} \mathrm{Nd} /{ }^{144} \mathrm{Nd}$. Bafang volcanic rocks have similar $\mathrm{Hf}$ and $\mathrm{Nd}$ isotopic compositions than the oceanic part of the CVL (not illustrated here), excepted for the most differentiated samples (hawaiites and mugearites) with least radiogenic $\mathrm{Nd}$ and $\mathrm{Hf}$ signatures. In Pb isotope diagrams (Fig. 6b) the Bafang lavas also lie close to the oceanic part of the CVL, with one hawaiite and three basanites having slightly less radiogenic $\mathrm{Pb}$ composition, similar to some contaminated samples from the Bamenda volcanic field (Kangang et al., 2013).

\section{Discussion}

\subsection{Fractional crystallization}

As shown before, primary melts in equilibrium with mantle peridotites are assumed to have Mg\# values of $68-72$ and high Ni (300 - 500 ppm) and Cr ( 1,000 ppm) contents (Frey et al. 1978; Tatsumi et al., 1983). Even if basanite sample BAF 45 is not far from these values $(\mathrm{Mg \#}=60.43, \mathrm{Ni}=261 \mathrm{ppm}$ and $\mathrm{Cr}=516 \mathrm{ppm})$, all the samples, even the most mafic ones, encountered crystal fractionation at some point.

As suggested on figure 4, major and compatible trace element variations are compatible with a fractionation of olivine, clinopyroxene and Fe-Ti oxide in the course of the magma 
differentiation. The fractionation of olivine is indicated by decreasing $\mathrm{MgO}$ and $\mathrm{Ni}$, while fractionation of clinopyroxene is indicated by decreasing of $\mathrm{CaO}$ and $\mathrm{Cr}$ with decreasing $\mathrm{Mg \#}$ (Fig. 4e-f). The decrease of $\mathrm{TiO}_{2}$, visible only for the most differentiated basalts, indicates a step of Fe-Ti oxides crystallization during the magma evolution (Fig. 4b).

The constant increase of $\mathrm{Al}_{2} \mathrm{O}_{3}$ during nearly all the differentiation indicates that plagioclase was not an important crystallizing phase during the fractional crystallization processes. This is also consistent with the absence of Eu or Sr depletion even in the most differentiated rocks (Fig. 5a).

The relatively wide age range covered by Bafang volcanic rocks (from 10.5 to $6.3 \mathrm{Ma}$ ) implies that the geochemical diversity reported here cannot be explained by a single differentiation trend but by several distinct magmatic series evolving independently, thus precluding any modelling of the fractional crystallization processes.

\subsection{Crustal contamination}

Some of the geochemical characteristics of Bafang volcanic rocks can be accounted for by interactions between melts and crustal rocks during the magma ascent toward the surface and its storage in magma chambers, since crustal contamination is an efficient way of modifying trace-element and isotopic composition (McDermott et al., 2005; Zellmer et al., 2005). The crust along the studied part of the CVL is made of Panafrican metasedimentary units and granitoids, but Paleoproterozoic to Archean lower crustal units have also been recognized (Marzoli et al., 2000; Kwekam et al., 2010). Former studies have already suggested that contamination of the primary magmas by mature and thickened crust is important along the Cameroon Volcanic Line (Halliday et al., 1988; Marzoli et al., 1999; Rankenburg et al., 2005; Kamgang et al., 2007, 2008, 2013). For example, this has already been clearly demonstrated for the felsic and mafic rocks from the Bamenda volcanic province nearby based on trace 
elements and isotopes (Kamgang et al. 2007, 2008, 2013). The effect of the CC can be recognized on figure 7 , by the correlation between the $\mathrm{MgO}$ contents and ${ }^{87} \mathrm{Sr} /{ }^{86} \mathrm{Sr}$ and between the silica and ${ }^{143} \mathrm{Nd} /{ }^{144} \mathrm{Nd}$ ratio. In basanites, the extent of this $\mathrm{CC}$ appears to be limited, since their isotopic compositions are barely modified. Some silica-saturated samples (BAF36, BAF42) are not contaminated and have isotopic properties similar to those of basanites. Two different trends of contamination can be identified on the $\mathrm{Hf}$ vs $\mathrm{Pb}$ isotopes diagram of figure 8. Samples BAF $10-15-18-43$ define a trend towards low ${ }^{178} \mathrm{Hf} /{ }^{177} \mathrm{Hf}$ and ${ }^{206} \mathrm{~Pb} /{ }^{204} \mathrm{~Pb}$, this group corresponds to the samples with the highest ${ }^{87} \mathrm{Sr} /{ }^{86} \mathrm{Sr}(>0.704)$. Samples BAF 2-3-37 also have low ${ }^{178} \mathrm{Hf} /{ }^{177} \mathrm{Hf}$ but they have more radiogenic $\mathrm{Pb}$ signature, similar to those of the uncontaminated rocks. These samples have probably been less affected by contamination processes, and/or have interacted with a different crustal component during differentiation. The BAF3 mugearite would appear to be uncontaminated, if it was not for its ${ }^{176} \mathrm{Hf} /{ }^{177} \mathrm{Hf}$, which is one among the lowest in Bafang data. Overall, if present, the effect of CC cannot be detected with trace elements.

\subsection{Mantle sources}

The lithospheric mantle is relatively cold $\left(<1300^{\circ} \mathrm{C}\right)$ and conductive and is often isotopically enriched (high ${ }^{87} \mathrm{Sr} /{ }^{86} \mathrm{Sr}$ and low ${ }^{143} \mathrm{Nd} /{ }^{144} \mathrm{Nd}$ values) because of its long isolation from the convective mantle and with the percolation of magmatic melts. In contrast, the asthenospheric mantle is hot and convective and is geochemically depleted, due to the extraction of crusts at subduction zones and the mid ocean ridges. One hint toward understanding whether melts were extracted from lithosphere or asthenosphere is to define if partial melting occurred in garnet or spinel stability field. If on one hand, spinel was present as a residual phase in the source, the lithospheric origin is attested. On the other hand, the presence of garnet would attest that partial melting occurred at a pressure greater than $3 \mathrm{GPa}$ (Robinson and Wood, 
1998), which corresponds to about a $70-80 \mathrm{~km}$ depth, while the present day (about $10 \mathrm{Ma}$ after Bafang volcanic activity) depth of the lithosphere/asthenosphere boundary lies below $120 \mathrm{~km}$ in this area (Fishwick, 2010; De Plaen et al., 2014). Residual garnet results in HREE depletion relative to LREE due to the strong retention of HREE in this mineral (e.g. Green et al., 1989; Jenner et al., 1994), and indeed, it is the case of some mafic volcanic rocks from this study, which are characterized by enrichments in the lightest, most incompatible REE, compared to the heaviest REE, with $(\mathrm{La} / \mathrm{Yb})_{\mathrm{N}}$, ranging from 11.5 to 19.8. These high values, together with $(\mathrm{Tb} / \mathrm{Yb})_{\mathrm{N}}$ of 1.9 to 2.9 (figure 9), falling in the range of garnet-bearing mantle source of Wang et al. (2002), demonstrate that garnet was involved during the extraction of the melts. Moreover, in order to obtain the REE patterns of Bafang mafic rocks, the CVL mantle source also needed to be geochemically richer (trace concentrations and isotopes) than the MORB asthenospheric mantle.

Even if basanites and alkali basalts share some geochemical similarities, and could therefore be believed as resulting from different degrees of partial melting of a single source, some isotopic differences among the least contaminated samples allow to distinguish two groups of samples and to testify of the geochemical non-homogeneity of the mantle source. On figure 10, $\mathrm{Hf}$ isotopes show clear correlations with $\mathrm{Th} / \mathrm{Y}$ and $\mathrm{Zr} / \mathrm{Hf}$ : samples with the highest $\varepsilon_{\mathrm{Hf}}$ have the lowest $\mathrm{Zr} / \mathrm{Hf}, \mathrm{La} / \mathrm{Yb}$ and $\mathrm{Th} / \mathrm{Y}$ ratios. The appearance of both basanites and basalts in the two isotopic trends confirms that their differences in major element compositions are more likely due to partial melting effects, than to source composition.

Because the $\mathrm{Sr}$ isotopes are similar for the ocean basalts of the CVL and our even most contaminated continental samples (figure 6), it is difficult to decipher between mantle source heterogeneities and crustal contamination processes, and it is suggested that the contamination processes have been often underestimated in previous studies concerning the continental volcanic rocks from Cameroon. Actually, together on figure 6, Bafang volcanic rocks and the 
ocean basalts of the CVL show up as a trend that could be accounted for by the mixture of three components : 1) the depleted MORB mantle (DMM) (which would not be dominant in the mixture); 2) an unidentified enriched component with radiogenic $\mathrm{Sr}$ and non-radiogenic $\mathrm{Nd}$; and 3) what appears to be the source of Mount Cameroun volcanic rocks (at the extremity of the CVL trend on figure 6) and is particularly rich in radiogenic $\mathrm{Pb}$.

On figure $11 \mathrm{a}, \mathrm{Pb}$ isotopic compositions of Bafang and some oceanic volcanic samples lie on a trend pointing towards the composition of Mount Cameroon but not St Helena. However, this contribution of the Mt Cameroon mantle source cannot be detected using $\mathrm{Nd}$ isotopes (Fig. 11b).

\subsection{Geodynamical consequences:}

As emphasized by Milelli et al. (2012), the fact that the magmatic activity has been sustained for about $70 \mathrm{Ma}$ all along the continental part of the CVL (Déruelle et al., 1991) indicates that, unlike in the traditional hotspot - lithospheric drift model, where plate cinematic constantly changes the position of the volcanic activity at the surface, the mantle source of the magmatism along the CVL is structurally associated to the continental crust and therefore, seems to lie within the subcontinental lithospheric mantle. As seen on the figure 11, the Bafang mafic rocks have isotopic compositions similar to both those of volcanic rocks from the continental and the oceanic (Bioko, Principe, Sao Tomé and Pagalu Islands) part of the CVL (Halliday et al., 1988; Lee et al., 1994; Ballentine et al., 1997). Then, how could a single source has been melting in both of these environments for about 70 Ma? Halliday et al. (1988) proposed that both the subcontinental and the ocean lithospheric mantle were impregnated during the Mesozoic by veins of asthenospheric melts issued from the St. Helena mantle plume, sited just below the CVL at that time. And the later melting of this re-fertilized "plume contaminated" material would account for the HIMU-like signature of some of the 
CVL basalts. Even if this model has been regularly adopted in the literature (Barfod et al., 1999; Rankenburg et al., 2005; and Yokoyama et al., 2007), Lee et al. (1994) alternatively suggested, based on geochemical evidence, a different scenario involving a sublithospheric hot zone periodically re-fed by HIMU-like deep mantle plumes. Moreover, seismic velocity data in the upper mantle, led Reusch et al. $(2010,2011)$ to the conclusion that there is no thermal anomaly in the upper mantle beneath the CVL deeper than the transition zone $(\sim 250 \mathrm{~km})$, and they attributed the origin of the magmatism to edge flow convection due to lateral variations of lithospheric thickness on the north-western side of the Congo craton. More recently, Milleli et al. (2012) and Fourel et al. (2013) proposed a model with similar endings, but a different driving mechanism. Based on laboratory experiments, they demonstrated that the lithosphere beneath continents can become instable, due to cooling from above. Through time, the instabilities will turn into linear upwellings and downwellings with a radial pattern from the centre of the continent. Partial melting in the SCLM could therefore appear in the upwelling regions while downwelling areas would induce compression in the crust above.

Altogether, our new data strongly advocate against an involvement of the St Helena hot spot track in the genesis of the oceanic and continental magmas along the CVL. Nevertheless there is magmatic activity all along the CVL and it has been continue for more than 70 My along a narrow area parallel to the Benue trough, located $\sim 200 \mathrm{~km}$ to the North, and perpendicularly to the continent border. Both this peculiar "Y" morphology, the timescale of its formation and evolution of CVL, and the absence of St-Helena plume geochemical imprint, suit adequately the edge flow convection (Reusch et al., 2010; 2011) or the upwelling-downwelling (Fourel et al., 2012; Milleli et al., 2012) models proposed by the geophysicists. 
Hints about the precise petrological composition of the melting source can be looked for within the trace element compositions illustrated in figure 5. As formerly noticed on these spidergrams, many mafic samples, which are not particularly rich in Ca feature positive Eu anomalies, sometimes associated with positive $\mathrm{Sr}$ anomaly without phenocrysts of plagioclase being involved. Such peculiarity has already been observed in lavas from the Bambouto volcanic province (Marzoli et al., 2000). Similar anomalies are also present in mafic rocks from the Bamenda Mountains, and Kamgang et al. (2007, 2013) argued that they are due to the melting of mafic mantle pyroxenites and the subsequent mixing of these magmas with magmas derived from the melting of lherzolites. Pyroxenites within the lithospheric mantle, could be the remnants of the crystallization of mafic magmas during either the circulation of the St Helena hot spot magmas or older magmatic events which have structured the SCLM in this region. The role of pyroxenite melting in the mantle remains to be clearly identified, and the nature and location of the source of the magmas all along the CVL is still not fully identified, however, the role of the St Helena hot spot is probably less important than previously proposed. More chemical and isotopic data on the oceanic and continental parts of the CVL as well as the modeling of the partial melting of pyroxenites, will help to further understand the origin of this peculiar and long-lasting magmatic province in West Africa.

\section{Conclusions}

Major and trace elements as well as $\mathrm{Sr}-\mathrm{Nd}-\mathrm{Pb}-\mathrm{Hf}$ isotopes determined on mafic and intermediate lavas from the Bafang area allow us to emphasize several points about the origin of the magmatism along the Cameroon Volcanic Line:

- Lavas of alkaline affinity were emplaced between 10 and $6 \mathrm{Ma}$ in the area of Bafang, in the continental part of the CVL. 
- The differentiation from basalts and basanites to mugearites is accounted for by the removal of olivine, clinopyroxene and oxides. Crustal contamination is present in some samples and modifies their isotopic composition.

- The isotopic composition of the uncontaminated samples is consistent with the participation of three distinct mantle components, the depleted MORB mantle (not dominant), an enriched component and $\mathrm{a} \mathrm{Pb}$ radiogenic component similar to the source of the Mont Cameroon.

- A mantle source with the composition of the ancient St Helena plume material is not required to explain the volcanism of the CVL, but mantle pyroxenites are probably involved during partial melting processes in the garnet facies. 


\section{Acknowledgements.}

We thank IRD (Institut de Recherche pour le Développement) for logistic support during field work in Cameroon. J. Langlade, C. Liorzou and C. Bassoulet are thanked for their help in the geochemical data acquisition. Comments by two reviewers were greatly appreciated and helped to improve the manuscript.

\section{References}

Aka, F.T., Nagao, K., Kusakabe, M., Sumino, H., Tanyileke, G., Ateba, B., Hell, J. (2004) Symmetrical helium isotope distribution on the Cameroon Volcanic Line,West Africa. Chem. Geol. 203, 205-223.

Anders, E. and Grevesse, N. (1989) Abundances of the elements: Meteoritic and solar. Geochim. Cosmochim. Acta 53, 197-214.

Ballentine, C.J., Lee, D-C., Halliday, A.N. (1997) Hafnium isotopic studies of the Cameroon line and new HIMU paradoxes. Chem. Geol. 139, 111-124.

Barfod, D.N., Ballentine, C.J., Halliday, A.N., Fitton, J.G. (1999) Noble gases in the Cameroon line and the He, $\mathrm{Ne}$, and Ar isotopic compositions of high $\mu$ (HIMU) mantle. J. Geophys. Res. 104, 29509-29527.

Barry, T.L., Saunders, A.D., Kempton, P.D., Windley, B.F., Pringle, M.S., Dorjnamjaa, D., Saandar, A. (2003) Petrogenesis of Cenozoic basalts from Mongolia: evidence for the role of asthenospheric versus metasomatized lithospheric mantle sources. J. Petrol. 44, 55-91.

Bellon, H., Quoc Buü, N., Chaumont, J., Philippet, J.C., 1981. Implantation ionique d'argon dans une cible support: application au traçage isotopique de l'argon contenu dans les minéraux et les roches. C. R. Acad. Sci. Paris 292, 977-980.

Blichert-Toft, J., Agranier, A., Andres, M., Kingsley, R., Schilling, J.-G., Albarède, F., 2005. Geochemical segmentation of the Mid-Atlantic Ridge north of Iceland and ridge-hot spot 
interaction in the North Atlantic. Geochem. Geophys. Geosyst. 6, Q01E19, doi:10.1029/2004GC000788.

Burke, K. (2001) Origin of the Cameroon Line of volcano-capped swells. J. Geol. 109, 349362.

Chaffey, D.J., Cliff, R.A., Wilson, B.M. (1989) Characterization of the St. Helena Magma Source Magmatism in the Ocean Basins. In: Saunders, A.D. and Norry, M.J. (Eds.) Geological Society of London, London, 257-276.

Chazot, G., Menzies, M. A., Harte, B. (1996) Determination of partition coefficients between apatite, clinopyroxene, amphibole, and melt in natural spinel lherzolites from Yemen: implications for wet melting of the lithospheric mantle. Geochim. Cosmochim. Acta 60, 423437.

Class, C. and Goldstein, S.L. (1997) Plume-lithosphere interactions in the ocean basins: constraints from the source mineralogy. Earth Planet. Sci. Lett. 150, 245-260.

Cotten, J., Le Dez, A., Bau, M., Caroff, M., Maury, R. C., Dulski, P., Fourcade, S., Bohn, M., Brousse, R. (1995) Origin of anomalous rare-earth element and yttrium enrichments in subaerially exposed basalts: evidence from French Polynesia. Chem. Geol., 119, 115-138.

Cox, A., Dalrymple, G. B. (1967) Statistical analysis of geomagnetic reversal data and the precision of potassium-argon dating. J. Geophys. Res., 72, 2603-2614.

De Plaen, R.S.M., Bastow, I.D., Chambers, E.L., Keir, D., Gallacher, R.J., Keane, J. (in press) The development of magmatism along the Cameroon Volcanic Line:Evidence from seismicity and seismic anisotropy. J. Geophys. Res., 119, 4233-4252, doi:10.1002/2013JB010583

Déruelle, B., Moreau, C., Nkoumbou, C., Kambou, R., Lisssom, J., Njonfang, E., Ghogomu, R.T., Nono, A. (1991) The Cameroon Line: a review. In: Kampunzu, A.B., Lubala, R. (Eds.), Magmatism in Extensional Structural Settings. The Phanerozoic African Plate. Springer, Berlin, New York, Heidelberg, 274-327. 
Déruelle, B., Ngounouno, I., Demaiffe, D. (2007) The "Cameroon Hot Line" (CHL): a unique example of active alkaline intraplate structure in both oceanic and continental lithospheres. C. R. Geosci. 339, 589-600.

Dumort , J.C. (1968) Cartes géologiques de reconnaissance à l'échelle de 1/50000.République Fédérale du Cameroun, Douala-Ouest, BRGM, Dir. Mines Geol., 68p.

Fishwick, S. (2010) Surface wave tomography: Imaging of the lithosphere-asthenopshere boundary beneath central and southern Africa? Lithos, 120, 63-73.

Fitton, J.G. and Dunlop, H.M. (1985) The Cameroon Line, West-Africa, and its bearing on the origin of Oceanic and Continental alkali basalt. Earth Planet. Sci. Lett. 72, 23-38.

Fourel, L., Milelli, L., Jaupart, C., Limare, A. (2013) Generation of continental rifts, basins, and swells by lithosphere instabilities. J. Geophys. Res., 118, 3080-3100.

Frey, F.A., Green, D.H., Roy, S.D. (1978) Integrated models of basalts petrogenesis: a study of quartz tholeiites to olivine melilites from South Eastern Australia utilizing geochemical and experimental petrological data. J. Petrol. 19, 463-513.

Green, T.H., Sie, S.H., Ryan, C.G., Cousens, D.R., 1989. Proton microprobe determined partitioning of $\mathrm{Nb}, \mathrm{Ta}, \mathrm{Zr}, \mathrm{Sr}$ and $\mathrm{Y}$ between garnet, clinopyroxene and basaltic magma at high pressure and temperature. Chem. Geol. 74, 201-216.

Halliday, A.N., Dickin, A.P., Fallick, A.E., Fitton, J.G. (1988) Mantle dynamics: a Nd, Sr, Pb and O isotopics study of the Cameroon line volcanic chain. J. Petrol. 29, 181-211.

Halliday, A.N., Davidson, J.P., Holden, P., DeWolf, C., Lee, D-C., Fitton, J.G. (1990) Traceelement fractionation in plumes and the origin of HIMU mantle beneath the Cameroon line. Nature 347, 523-528.

Hoffmann, A.W. (1988) Chemical differentiation of the Earth. The relationship between mantle, continental crust and oceanic crust. Earth Planet. Sci. Lett. 90, 297-314. 
Irvine, T.N., and Baragar, W.R.A., 1971, A guide to the chemical classification of the common volcanic rocks: Can J. Earth Sci., 523-548.

Jenner, G.A., Foley, S.F., Jackson, S.E., Green, T.H., Fryer, B.J., Longerich HP (1994) Determination of partition coefficients for trace elements in high pressure-temperature experimental run products by laser ablation microprobe-inductively coupled plasma mass spectrometry (LAM-ICP-MS). Geochim. Cosmochim. Acta, 58, 5099-5130.

Jung, S. and Masberg, P. (1998) Major and trace element systematics and isotope geochemistry of Cenozoic mafic volcanic from the Vogelsberg (Central Germany): constraints on the origin of continental alkaline and tholeiitic basalts and their mantle sources. J. Volcanol. Geotherm. Res. 86, 151-177.

Kamgang, P., Njonfang, E., Chazot, G., Tchoua, F. (2007) Géochimie et géochronologie des laves felsiques des Monts Bamenda NW -Cameroun (Ligne du Cameroun), C.R. Geosciences, $339,659-666$.

Kamgang, P., Chazot, G., Njonfang, E., Tchoua, F. (2008) Geochemistry and geochronology of mafi c rocks from Bamenda Mountains (Cameroon): Source composition and crustal contamination along the Cameroon volcanic line: C. R. Geosciences, 340, 850-857.

Kamgang, P., Chazot, G., Njonfang, E., Ngongang Tchuimegnie, N.B., Tchoua, F. (2013) Mantle sources and magma evolution beneath the Cameroon Volcanic Line: Geochemistry of mafic rocks from the Bamenda Mountains (NW Cameroon). Gond. Res., 24, 727-741.

Kampunzu, A.B. and Popoff, M. (1991) Distribution of the main Phanerozoic African rifts and associated magmatism, introductory notes. In: Kampunzu AB, Lubala R. (Eds.), Magmatism in Extensional Structural Settings, The Phanerozoic African Plate. Springer, Berlin, New York, Heidelberg, 2-10. 
Kawabata, H., Hanyu, T., Chang, Q., Kimura, J-I., Nichols, A.R., Tatsumi, Y. (2011) The Petrology and Geochemistry of St. Helena Alkali Basalts: Evaluation of the Oceanic Crustrecycling Model for HIMU OIB. J. Petrol. 52, 791-838.

Kwékam, M., Liègeois, J-P., Njonfang, E., Affaton, P. Tchoua, F. (2010) Nature, origin and significance of the Fomopéa Pan-African high-K-calc-alcaline plutonic complex in the Central African fold belt (Cameroon). J. Afr. Earth Sci., 57, 79-95.

Le Bas, M.J., Le Maitre, R.W., Streckeisen, A,, Zanettin, B. (1986) A chemical classification of volcanic rocks based on the total alkali-silica diagram. J. Petrol. 27, 745-750.

Lee, D.C., Halliday, A.N., Fitton, G.J., Poli, G. (1994) Isotopic variations with distance and time in the volcanic islands of the Cameroon Line: evidence of the mantle plume origin. Earth Planet. Sci. Lett. 123, 119-138.

Li, Z.-X. A. and Lee, C-T.A. (2006) Geochemical investigation of serpentinized oceanic lithospheric mantle in the Feather River Ophiolite, California: Implications for the recycling rate of water by subduction, Chem. Geol., 235, 161- 185 .

Marzoli, A., Renne, P.R., Peccirillo, E.M., Francesca, C., Bellieni, G., Melfi, A.J., Nyobe J.B., N'i J. (1999) Silicic magmas from the continental Cameroon Volcanic Line (Oku, Bambouto and Ngaoundere) $:{ }^{40} \mathrm{Ar}-{ }^{39} \mathrm{Ar}$ dates, petrology, Sr-Nd-O isotopes and their petrogenetic significance. Contrib. Mineral. Petrol., 135, 133-150.

Marzoli, A., Peccirillo, E.M., Renne, P.R., Bellieni, G., Iacumin, M., Nyobe, J.B., Tongwa, A.T. (2000) The Cameroon Volcanic Line revisited: petrogenesis of continental basaltic magmas from lithospheric and asthenospheric mantle sources. J. Petrol. 41, 87-109.

Mcdermott, F., Delfin, F.G., Defant, M.J., Turner, S., Maury, R. (2005) The petrogenesis of magmas from Mt. Bulusan and Mayon in the Bicol arc, the Philippines. Contrib. Mineral. Petrol. 150, 652-670 
McDonough, W.F. (2003) Compositional model for the Earth's core. In the Mantle and Core

(Eds. R.W. Carlson) vol. 2. Treatise on Geochemistry (Eds. H.D. Holland and K.K. Turekian). Elservier. Perganon, Oxford, 547-568.

McKenzie, D. and O’Nions, R.K. (1995) The source regions of ocean island basalts. J. Petrol. $36,133-160$.

Meysen, C.M., Blichert-Toft, J., Ludden, J.N., Humler, E., Mével, C., Albarède, F. (2007) Isotopic portrayal of the Earth's upper mantle flow field. Nature, 447, 1069-1074.

Middlemost, E.A.K. (1975) The basalt clan. Earth Sci. Rev. 11, 337-364.

Milelli L, Fourel L, Jaupart C (2012) A lithospheric instability origin for the Cameroon Volcanic Line. Earth Planet. Sci. Lett. 335-336, 80-87.

Nana, J. M. (1998) Le complexe volcano-plutonique de Bana (Ouest Cameroun : géologie et pétrologie. Thèse de l'Université Paris sud Orsay, 131 p.

Nguiessi, C.T. and Vialette, Y. (1994) Rb-Sr, Pb-Pb, U-Pb dating in the Bandja plutonic series of western Cameroon. C. R. Acad. Sci. Paris 319, 317-324.

Nguiessi, C.T., Nzenti, J-P., Nsifa, N.E., Tempier, P., Tchoua, F. (1997) A calc-alkaline magmatic complex from Bandja in the northequatorial fold belt: a synkinematic emplacement of plutonic rocks in a sinistral strike-slip shear zone from Pan-African age. C. R. Acad. Sci. Paris $325,95-101$.

Nzolang, C., Kagami, H., Nzenti, J.P., Holtz, F. (2003) Geochemistry and preliminary data on the Neoproterozoic granitoids from the Bantoun area, West Cameroon: evidence for a derivation from a Paleoproterozoic to Archean crust. Polar. Geosci. 16, 196-226.

Pang, K-N., Chung, S-L., Zarrinkoub, M.H., Mohammadi, S.S., Yang, H-M., Chu, C-H., Lee, H-Y., Lo, C-H. (2012) Age, geochemical characteristics and petrogenesis of Late Cenozoic intraplate alkali basalts in the Lut-Sistan region, eastern Iran. Chem. Geol. 306-307, 40-53. 
Pouclet, A., Dongmo, A. K., Bardintzeff, J. M., Wandji, P., Tagheu , P. C., Nkouathio, D.,

Bellon, H., Ruffet, G. (2014) The Mount Manengouba, a complex volcano of the Cameroon line: volcanic history, petrological and geochemical features. J. Afr. Earth Sci. 97, 297-321.

Rankenburg, K., Lassiter, J.C., Brey, G. (2005) The role of the continental crust and lithospheric mantle in the genesis of Cameroon volcanic line lavas: constraints from isotopic variations in lavas and megacrysts from the Biu and Jos Plateaux. J. Petrol. 46, 169-190.

Reusch, M.A., Nyblade, A.A., Wiens, A.D., Shore, J.P., Bekoa, A., Tabod, T.C., Nnange, M.J. (2010) Upper mantle structure beneath Cameroon from body waye tomography and the origin of the origin of the Cameroon Volcanic Line. Geochem. Geophys. Geosyst. 11, Q10W07, doi:10.1029/2010GC003200.

Reusch, M.A., Nyblade, A.A., Tibi, R., Wiens, A.D., Shore, J.P., Bekoa, A., Tabod, T.C. ,Nnange, M.J. (2011) Mantle transition zone thickness beneath Cameroon: evidence for an upper mantle origin for the Cameroon Volcanic Line. Geophys. J. Int. 187, 1146-1150.

Robinson, J.A.C. and Wood, B.J. (1998) The depth of the spinel to garnet transition at the peridotites solidus. Earth Planet. Sci. Lett., 164, 277-284.

Salters, V.J.M. and White, W.M. (1998) Hf isotope constraints on mantle evolution. Chem. Geol., 145, 447-460.

Steiger, R. H. and Jäger, E. (1977) Subcommission on geochronology : convention on the use of decay constants in geo and cosmochronology. Earth Planet. Sci. Lett. 36, 359-362.

Sun, S-S. and McDonough, W.F. (1989) Chemical and isotopic systematic of oceanic basalts: implications for mantle composition and processes. In: Saunders AD, Norry MJ (eds) Magmatism in the Ocean Basins. Geological Society, London, Special Publication 42, 313345. 
Tatsumi, Y.M., Sakuyama, H., Fukuyama, H., Kushiro, I. (1983) Generation of basalt magmas and the thermal structure of the mantle wedge in subduction zones. J. Geophys. Res. $88,5815-5825$.

Thirlwall, M.F. (2000) Inter-laboratory and other errors in $\mathrm{Pb}$ isotope analyses investigated using a 207Pb-204Pb double spike. Chem. Geol., 163, 299-322.

Tsafack, J-P.F., Wandji, P., Bardintzeff, J-M., Bellon, H., Guillou, H. (2009) The Mount Cameroon stratovolcano (Cameroon Volcanic Line, Central Africa): Petrology, geochemistry, isotope and age data. Mineral. Petrol., 47, 65-78.

Wang K, Plank T, Walker JD, Smith EI (2002) A mantle melting profile across the basin and range, SW USA. J. Geophys. Res., 107, ECV5, 1-21.

Wotchoko , P., Wandji, P., Bardintzeff, J. M., Bellon, H. (2005) Données pétrologiques et géochronologiques nouvelles sur le volcanisme alcalin néogène à recent de la rive oust du Noun (plaine du Noun, Ligne du Cameroun) Review of the Bulgarian Geological Society , 66, 97-105.

Wulff-Pedersen, E., Neumann, E.R., Jensen, B.B. (1996) The upper mantle under La Palma, Canary Islands: formation of $\mathrm{Si}-\mathrm{K}-\mathrm{Na}$ rich melt and its importance as a metasomatic agent. Contrib. Mineral. Petrol. 125, 113-139.

Yokoyama, T., Aka, F.T., Kusakabe, M., Nakamura, E. (2007) Plume-lithosphere interaction beneath Mt. Cameroon volcano, West Africa: constraints from ${ }^{238} \mathrm{U}^{230}{ }^{23 h}-{ }^{226} \mathrm{Ra}$ and $\mathrm{Sr}-\mathrm{Nd}-$ $\mathrm{Pb}$ isotopes systematics. Geochim. Cosmochim. Acta 71, 1835-1854.

Youmen, D. (1994) Evolution volcanologique, pétrologique et temporelle de la caldera des monts Bambouto (Cameroun).Thèse Université de Kiel, Allemagne, 273 p. Zellmer, G.F., Annen, C., Charlier, B.L.A., George, R.M.M., Turner, S.P., Hawkesworth, C.J. (2005) Magma evolution and ascent at volcanic arcs: constraining petrogenetic processes through rates and chronologies. J. Volcanol. Geotherm. Res. 140, 171-191 
Zindler, A. and Hart. S. (1986) Chemical geodynamics. An. Rev. Earth Planet. Sci. 14, 493571

Zou, H., Zindler, A., Xu, X., Qi, Q. (2000) Major, trace element, and Nd, Sr, and Pb isotope studies of Cenozoic basalts in SE China: mantle sources, regional variations, and tectonic significance. Chem. Geol. 171, 33-47.

\section{Figure captions}

Figure 1: Location of the Bafang area (white square) along the Cameroon Volcanic Line (adapted after Halliday et al., 1988). Location of seamounts after Burke (2001). Inset, bottom right is after Kampunzu and Popoff (1991).

Figure 2: Simplified geological map of the studied area (after Dumort, 1968, modified) and location of the samples. Their age is indicated when known.

Figure 3: Total alkali vs. silica (T.A.S.) classification diagram for the Bafang lavas (Le Bas et al., 1986). Inset: $\mathrm{Na}_{2} \mathrm{O}$ vs. $\mathrm{K}_{2} \mathrm{O}$ subdivision diagram of the alkaline series (Middlemost 1975). The alkaline-subalkaline dividing line is from Irvine and Baragar (1971).

Figure 4: $\mathrm{SiO}_{2}$ (a), $\mathrm{TiO}_{2}$ (b), $\mathrm{Al}_{2} \mathrm{O}_{3}$ (c), $\mathrm{Na}_{2} \mathrm{O}$ (d), $\mathrm{CaO}$ (e) and $\mathrm{Ni}$ (f) vs. $\mathrm{Mg} \#$ for the Bafang volcanic rocks. Arrows indicate qualitative effects of mineral fractionation. Symbols as in Figure 3. 
Figure 5: (a) Chondrite-normalized REE patterns and (b) primitive mantle-normalized multielement patterns for the Bafang volcanic rocks. Chondrite normalization values are from Anders and Grevesse (1989), Primitive Mantle normalization values are from McDonough (2003). The data for N-MORB and E-MORB are from Sun and McDonough (1989). The data for Mount Cameroon (Yokoyama et al., 2007) and St Helena (Kawabata et al., 2011) are also shown for comparison. Symbols as in Figure 3.

Figure 6: ${ }^{143} \mathrm{Nd} /{ }^{144} \mathrm{Nd}$ vs. ${ }^{87} \mathrm{Sr} /{ }^{86} \mathrm{Sr}$ (a) and ${ }^{207} \mathrm{~Pb} /{ }^{204} \mathrm{~Pb}$ vs. ${ }^{206} \mathrm{~Pb} /{ }^{204} \mathrm{~Pb}$ (b) diagrams for the Bafang volocanic rocks. HIMU, FOZO and EMII values are from Zindler and Hart (1986). Data for the CVL and Mt Cameroon are from Halliday et al. (1988), Lee et al. (1994), Ballentine et al. (1997), Marzoli et al. (2000), Rankenburg et al. (2005), Yokoyama et al. (2007), Tsafack et al. (2009), Kamgang et al. (2013). Data for the Atlantic MORB are from Meyzen et al. (2007). Data for St Helena are from Chaffey (1989), Salters et al. (1998) and Thirlwall (2000). Symbols as in Figure 3.

Figure 7: ${ }^{87} \mathrm{Sr} /{ }^{86} \mathrm{Sr}$ vs. $\mathrm{MgO}$ (a) and ${ }^{143} \mathrm{Nd} /{ }^{144} \mathrm{Nd}$ vs. $\mathrm{SiO}_{2}$ (b) for the Bafang volcanic rocks showing the AFC trends followed by some of the most differentiated samples. Symbols as in Figure 3.

Figure 8: ${ }^{176} \mathrm{Hf} /{ }^{177} \mathrm{Hf}$ vs. ${ }^{206} \mathrm{~Pb} /{ }^{204} \mathrm{~Pb}$ diagram showing two different trends of crustal contamination for some of the Bafang volcanic rocks. Symbols as in Figure 3.

Figure 9: Primitive mantle normalized $(\mathrm{Tb} / \mathrm{Yb})_{\mathrm{N}}$ vs. Th for the Bafang volcanic rocks (after Wang et al., 2002). Symbols as in Figure 3. 
Figure 10: ${ }^{176} \mathrm{Hf} /{ }^{177} \mathrm{Hf}$ vs. Th/Y (a) and ${ }^{176} \mathrm{Hf} /{ }^{177} \mathrm{Hf}$ vs. $\mathrm{Zr} / \mathrm{Hf}$ (b) diagrams for the Bafang volcanic rocks. Symbols as in Figure 3.

Figure 11: ${ }^{208} \mathrm{~Pb} /{ }^{204} \mathrm{~Pb}$ vs. ${ }^{206} \mathrm{~Pb} /{ }^{204} \mathrm{~Pb}$ (a) and ${ }^{143} \mathrm{Nd} /{ }^{144} \mathrm{Nd}$ vs ${ }^{206} \mathrm{~Pb} /{ }^{204} \mathrm{~Pb}$ (b) diagrams with only the uncontaminated mafic rocks from Bafang. FOZO and EMII values are from Zindler and Hart (1986). Data for the CVL and Mt Cameroon are from Halliday et al. (1988), Lee et al. (1994), Ballentine et al. (1997), Marzoli et al. (2000), Rankenburg et al. (2005), Yokoyama et al. (2007), Tsafack et al. (2009), Kamgang et al. (2013). Data for the Atlantic MORB are from Meyzen et al. (2007). Data for St Helena are from Chaffey (1989), Salters et al. (1998) and Thirlwall (2000). Symbols as in Figure 3. 
Table 1. Major (wt.\%) and trace (ppm) element data for the Bafang lavas.

\begin{tabular}{|c|c|c|c|c|c|c|}
\hline Latitude: & N0511'47.1" & N05ำ' $10^{\prime} 22.5^{\prime \prime}$ & N05²13'19.1" & N0504'27.2" & N05¹0'59.8" & N05 $11^{\prime} 46.8^{\prime \prime}$ \\
\hline Longitude: & $\mathrm{E} 10^{\circ} 13^{\prime} 08.2^{\prime \prime}$ & $\mathrm{E} 10^{\circ} 12^{\prime} 31.9^{\prime \prime}$ & E10¹7'41.4" & $\mathrm{E} 10^{\circ} 10^{\prime} 14.0^{\prime \prime}$ & $\mathrm{E} 10^{\circ} 17^{\prime} 38.8^{\prime \prime}$ & $\mathrm{E} 10^{\circ} 19^{\prime} 22.1^{\prime \prime}$ \\
\hline Rocks type & Basanites & & & & & \\
\hline Samples & BAF 5a & BAF 11 & BAF 22 & BAF 34 & BAF 44 & BAF 45 \\
\hline $\mathrm{SiO}_{2}$ & 44.32 & 44.36 & 42.52 & 43.44 & 43.41 & 42.80 \\
\hline $\mathrm{TiO}_{2}$ & 2.81 & 2.92 & 3.34 & 2.87 & 3.25 & 3.22 \\
\hline $\mathrm{Al}_{2} \mathrm{O}_{3}$ & 16.25 & 16.28 & 13.04 & 13.44 & 13.16 & 12.22 \\
\hline $\mathrm{Fe}_{2} \mathrm{O}_{3} \mathrm{t}$ & 13.08 & 13.23 & 13.73 & 13.05 & 13.57 & 13.02 \\
\hline $\mathrm{MnO}$ & 0.22 & 0.22 & 0.24 & 0.21 & 0.19 & 0.20 \\
\hline $\mathrm{MgO}$ & 4.97 & 5.22 & 10.49 & 9.52 & 10.08 & 11.81 \\
\hline $\mathrm{CaO}$ & 8.74 & 8.91 & 11.04 & 10.19 & 10.53 & 11.09 \\
\hline $\mathrm{Na}_{2} \mathrm{O}$ & 3.78 & 4.24 & 2.21 & 2.45 & 2.70 & 3.29 \\
\hline $\mathrm{K}_{2} \mathrm{O}$ & 1.64 & 1.69 & 1.47 & 1.32 & 1.27 & 1.35 \\
\hline $\mathrm{P}_{2} \mathrm{O}_{5}$ & 1.42 & 1.37 & 0.75 & 0.78 & 0.70 & 0.71 \\
\hline LOI & 1.71 & 0.63 & 1.68 & 1.85 & 1.15 & 0.33 \\
\hline TOTAL & 98.93 & 99.06 & 100.50 & 99.11 & 100.01 & 100.06 \\
\hline $\mathrm{Mg \#}$ & 39.04 & 39.92 & 56.27 & 55.13 & 55.56 & 60.43 \\
\hline $\mathrm{Sc}$ & 14.28 & 16.84 & 29.50 & 25.36 & 28.54 & 29.73 \\
\hline V & 176.6 & 197.3 & 271.5 & 242.8 & 263.6 & 276.9 \\
\hline $\mathrm{Cr}$ & 12.51 & 18.89 & 285.0 & 282.5 & 255.7 & 515.6 \\
\hline $\mathrm{Mn}$ & 1689 & 1726 & 1889 & 1703 & 1563 & 1638 \\
\hline $\mathrm{Co}$ & 34.02 & 37.20 & 59.49 & 52.38 & 56.32 & 59.96 \\
\hline $\mathrm{Ni}$ & 18.91 & 24.72 & 190.3 & 185.7 & 180.2 & 261.4 \\
\hline $\mathrm{Cu}$ & 25.68 & 29.11 & 53.48 & 50.65 & 52.01 & 59.70 \\
\hline $\mathrm{Zn}$ & 125.7 & 134.2 & 108.9 & 118.4 & 113.1 & 107.8 \\
\hline $\mathrm{Ga}$ & 20.87 & 21.12 & 17.83 & 19.43 & 18.58 & 18.02 \\
\hline $\mathrm{Rb}$ & 45.34 & 40.41 & 34.56 & 35.23 & 27.87 & 41.22 \\
\hline $\mathrm{Li}$ & 10.57 & 11.57 & 5.92 & 8.14 & 6.57 & 8.42 \\
\hline $\mathrm{Be}$ & 3.09 & 3.14 & 1.48 & 1.88 & 1.55 & 1.77 \\
\hline $\mathrm{Sr}$ & 1366 & 118 & 925.3 & 994.1 & 973.6 & 920.4 \\
\hline $\mathrm{Y}$ & 32.54 & 34.02 & 31.12 & 33.45 & 32.38 & 32.33 \\
\hline $\mathrm{Zr}$ & 282.0 & 283.8 & 247.1 & 324.3 & 256.0 & 287.3 \\
\hline $\mathrm{Nb}$ & 84.92 & 84.34 & 74.99 & 94.93 & 75.09 & 95.83 \\
\hline Cs & 0.90 & 0.47 & 0.36 & 0.66 & 0.34 & 0.55 \\
\hline $\mathrm{Ba}$ & 659.9 & 648.6 & 480.4 & 559.8 & 497.0 & 557.1 \\
\hline $\mathrm{La}$ & 53.26 & 52.42 & 47.62 & 69.15 & 48.62 & 57.16 \\
\hline $\mathrm{Ce}$ & 109.9 & 107.4 & 98.0 & 135.6 & 100.2 & 112.3 \\
\hline $\operatorname{Pr}$ & 13.84 & 13.42 & 12.04 & 16.16 & 12.33 & 13.62 \\
\hline $\mathrm{Nd}$ & 54.83 & 54.36 & 48.72 & 60.34 & 49.35 & 52.71 \\
\hline $\mathrm{Sm}$ & 10.38 & 10.26 & 9.36 & 10.54 & 9.58 & 9.89 \\
\hline $\mathrm{Eu}$ & 3.27 & 3.23 & 3.00 & 3.24 & 3.06 & 3.08 \\
\hline Gd & 8.87 & 8.85 & 8.32 & 8.73 & 8.50 & 8.60 \\
\hline $\mathrm{Tb}$ & 1.18 & 1.19 & 1.14 & 1.20 & 1.16 & 1.17 \\
\hline Dy & 6.26 & 6.24 & 6.01 & 6.30 & 6.20 & 6.21 \\
\hline Ho & 1.14 & 1.16 & 1.10 & 1.16 & 1.12 & 1.13 \\
\hline $\mathrm{Er}$ & 2.85 & 2.92 & 2.73 & 2.91 & 2.84 & 2.85 \\
\hline $\mathrm{Tm}$ & 2.56 & 2.57 & 2.79 & 2.24 & 2.52 & 2.43 \\
\hline $\mathrm{Yb}$ & 2.29 & 2.32 & 2.16 & 2.38 & 2.18 & 2.25 \\
\hline $\mathrm{Lu}$ & 0.31 & 0.32 & 0.29 & 0.33 & 0.30 & 0.31 \\
\hline $\mathrm{Hf}$ & 5.76 & 5.76 & 5.23 & 6.39 & 5.31 & 5.74 \\
\hline $\mathrm{Ta}$ & 4.72 & 4.60 & 4.01 & 3.71 & 3.72 & 5.32 \\
\hline W & 0.70 & 0.75 & 0.34 & 0.65 & 0.66 & 1.28 \\
\hline $\mathrm{Pb}$ & 4.12 & 4.07 & 2.10 & 3.50 & 2.22 & 3.01 \\
\hline Th & 4.78 & 4.70 & 4.47 & 6.92 & 4.31 & 6.19 \\
\hline $\mathrm{U}$ & 1.33 & 1.26 & 1.12 & 1.76 & 1.12 & 1.64 \\
\hline
\end{tabular}




\begin{tabular}{|c|c|c|c|c|c|}
\hline Latitude: & N0509'10.9" & N0509'42.9" & N0506'14.7" & N0509'24.7" & N05 $09^{\prime} 44.3^{\prime \prime}$ \\
\hline Longitude: & E10¹7'53.4" & $\mathrm{E} 10^{\circ} 18^{\prime} 21.5^{\prime \prime}$ & $\mathrm{E} 10^{\circ} 10^{\prime} 10.0^{\prime \prime}$ & $\mathrm{E} 10^{\circ} 18^{\prime} 00.5^{\prime \prime}$ & $\mathrm{E} 10^{\circ} 17^{\prime} 43.7^{\prime \prime}$ \\
\hline Rocks type & Basalts & & & & \\
\hline Samples & BAF 15 & BAF 18 & BAF 36 & BAF 42 & BAF 43 \\
\hline $\mathrm{SiO}_{2}$ & 46.33 & 47.12 & 45.45 & 44.93 & 46.76 \\
\hline $\mathrm{TiO}_{2}$ & 3.17 & 3.27 & 3.00 & 2.96 & 3.18 \\
\hline $\mathrm{Al}_{2} \mathrm{O}_{3}$ & 15.63 & 15.91 & 15.50 & 14.19 & 15.67 \\
\hline $\mathrm{Fe}_{2} \mathrm{O}_{3} \mathrm{t}$ & 12.95 & 13.12 & 13.82 & 11.44 & 12.99 \\
\hline $\mathrm{MnO}$ & 0.17 & 0.20 & 0.22 & 0.18 & 0.17 \\
\hline $\mathrm{MgO}$ & 6.51 & 6.34 & 5.77 & 9.12 & 6.69 \\
\hline $\mathrm{CaO}$ & 8.62 & 8.79 & 7.97 & 9.42 & 8.41 \\
\hline $\mathrm{Na}_{2} \mathrm{O}$ & 3.40 & 3.76 & 3.38 & 2.77 & 3.39 \\
\hline $\mathrm{K}_{2} \mathrm{O}$ & 1.22 & 1.24 & 1.29 & 1.90 & 1.22 \\
\hline $\mathrm{P}_{2} \mathrm{O}_{5}$ & 0.53 & 0.51 & 1.28 & 0.68 & 0.53 \\
\hline LOI & 0.67 & -0.41 & 1.79 & 2.26 & 0.59 \\
\hline TOTAL & 99.21 & 99.86 & 99.47 & 99.84 & 99.60 \\
\hline $\mathrm{Mg} \#$ & 45.85 & 44.88 & 41.30 & 57.31 & 46.46 \\
\hline $\mathrm{Sc}$ & 20.35 & 21.49 & 17.52 & 19.59 & 21.47 \\
\hline V & 217.6 & 230.7 & 158.7 & 216.2 & 228.7 \\
\hline $\mathrm{Cr}$ & 125.6 & 115.7 & 67.26 & 273.6 & 124.9 \\
\hline $\mathrm{Mn}$ & 1311 & 1576 & 1654 & 1389 & 1383 \\
\hline $\mathrm{Co}$ & 46.78 & 47.90 & 37.00 & 47.87 & 47.91 \\
\hline $\mathrm{Ni}$ & 82.05 & 81.70 & 50.66 & 155.9 & 85.43 \\
\hline $\mathrm{Cu}$ & 41.21 & 35.83 & 35.64 & 38.41 & 45.59 \\
\hline $\mathrm{Zn}$ & 109.3 & 109.9 & 110.8 & 110.0 & 110.8 \\
\hline $\mathrm{Ga}$ & 19.00 & 19.73 & 18.97 & 20.15 & 20.32 \\
\hline $\mathrm{Rb}$ & 20.27 & 24.19 & 17.59 & 42.12 & 22.28 \\
\hline $\mathrm{Li}$ & 7.06 & 7.32 & 6.46 & 6.35 & 7.23 \\
\hline $\mathrm{Be}$ & 1.28 & 1.32 & 1.34 & 2.07 & 1.40 \\
\hline $\mathrm{Sr}$ & 1000 & 782.9 & 1021 & 1011 & 817.4 \\
\hline Y & 25.85 & 27.72 & 33.94 & 25.82 & 27.41 \\
\hline $\mathrm{Zr}$ & 202.1 & 206.5 & 218.7 & 263.7 & 212.1 \\
\hline $\mathrm{Nb}$ & 55.91 & 50.67 & 60.97 & 82.76 & 58.71 \\
\hline Cs & 0.64 & 0.43 & 0.23 & 0.46 & 0.34 \\
\hline $\mathrm{Ba}$ & 439.8 & 427.3 & 582.9 & 615.3 & 440.3 \\
\hline $\mathrm{La}$ & 34.71 & 33.83 & 44.69 & 44.80 & 35.97 \\
\hline $\mathrm{Ce}$ & 70.38 & 69.31 & 96.84 & 88.50 & 72.35 \\
\hline $\operatorname{Pr}$ & 8.61 & 8.43 & 12.70 & 10.93 & 8.99 \\
\hline $\mathrm{Nd}$ & 34.53 & 34.19 & 54.56 & 43.62 & 35.86 \\
\hline $\mathrm{Sm}$ & 6.99 & 6.98 & 10.82 & 8.57 & 7.16 \\
\hline $\mathrm{Eu}$ & 2.41 & 2.44 & 4.05 & 2.75 & 2.49 \\
\hline $\mathrm{Gd}$ & 6.53 & 6.61 & 9.83 & 7.49 & 6.67 \\
\hline $\mathrm{Tb}$ & 0.90 & 0.93 & 1.30 & 1.00 & 0.94 \\
\hline Dy & 4.91 & 5.04 & 6.75 & 5.15 & 5.05 \\
\hline Ho & 0.91 & 0.96 & 1.24 & 0.91 & 0.93 \\
\hline $\mathrm{Er}$ & 2.28 & 2.45 & 2.96 & 2.20 & 2.37 \\
\hline $\mathrm{Tm}$ & 2.42 & 2.47 & 2.30 & 2.13 & 2.09 \\
\hline $\mathrm{Yb}$ & 1.81 & 1.97 & 2.19 & 1.65 & 1.86 \\
\hline $\mathrm{Lu}$ & 0.25 & 0.27 & 0.30 & 0.22 & 0.26 \\
\hline $\mathrm{Hf}$ & 4.39 & 4.32 & 4.72 & 5.31 & 4.43 \\
\hline $\mathrm{Ta}$ & 3.16 & 2.54 & 3.40 & 4.45 & 3.12 \\
\hline W & 0.26 & 0.54 & 0.17 & 0.98 & 0.63 \\
\hline $\mathrm{Pb}$ & 2.17 & 2.06 & 1.78 & 2.43 & 2.10 \\
\hline Th & 3.46 & 3.23 & 3.23 & 4.67 & 3.39 \\
\hline $\mathrm{U}$ & 0.89 & 0.83 & 0.90 & 1.39 & 0.86 \\
\hline
\end{tabular}




\begin{tabular}{|c|c|c|c|c|c|c|c|}
\hline Latitude: & N05²12'08.5" & N0509'51.5" & N0509'40.8" & N0504'49.4" & N0507'51.1" & N0509'40.5" & N05 $09^{\prime} 42.2^{\prime \prime}$ \\
\hline Longitude: & $\mathrm{E} 10^{\circ} 11^{\prime} 17.5^{\prime \prime}$ & $\mathrm{E} 10^{\circ} 15^{\prime} 04.4^{\prime \prime}$ & E10¹4'29.2" & E1009'51.9" & E1009'14.0" & E10¹0'08.4" & $\mathrm{E} 10^{\circ} 11^{\prime} 51.8^{\prime \prime}$ \\
\hline Rocks type & Hawaiites & & & & & & \\
\hline Samples & BAF 2 & BAF 10 & BAF 13 & BAF 33 & BAF 38 & BAF 40 & BAF 46 \\
\hline $\mathrm{SiO}_{2}$ & 48.60 & 47.77 & 47.44 & 47.52 & 47.38 & 46.93 & 47.30 \\
\hline $\mathrm{TiO}_{2}$ & 2.46 & 2.55 & 2.65 & 2.66 & 2.47 & 2.83 & 2.70 \\
\hline $\mathrm{Al}_{2} \mathrm{O}_{3}$ & 16.51 & 16.75 & 16.76 & 16.68 & 15.26 & 16.57 & 16.71 \\
\hline $\mathrm{Fe}_{2} \mathrm{O}_{3} \mathrm{t}$ & 13.01 & 13.30 & 13.48 & 13.80 & 12.66 & 14.03 & 13.65 \\
\hline $\mathrm{MnO}$ & 0.22 & 0.23 & 0.22 & 0.23 & 0.25 & 0.23 & 0.22 \\
\hline $\mathrm{MgO}$ & 3.60 & 3.86 & 3.99 & 3.70 & 5.47 & 4.33 & 3.77 \\
\hline $\mathrm{CaO}$ & 5.88 & 6.70 & 6.92 & 6.22 & 6.92 & 7.03 & 7.15 \\
\hline $\mathrm{Na}_{2} \mathrm{O}$ & 4.72 & 3.94 & 3.97 & 4.27 & 3.58 & 3.66 & 4.35 \\
\hline $\mathrm{K}_{2} \mathrm{O}$ & 2.04 & 1.99 & 1.89 & 1.93 & 2.12 & 1.79 & 1.97 \\
\hline $\mathrm{P}_{2} \mathrm{O}_{5}$ & 1.00 & 0.76 & 0.75 & 0.98 & 1.17 & 0.75 & 0.75 \\
\hline LOI & 1.19 & 1.22 & 1.54 & 1.29 & 2.27 & 2.01 & 0.74 \\
\hline TOTAL & 99.23 & 99.05 & 99.60 & 99.28 & 99.55 & 100.16 & 99.31 \\
\hline $\mathrm{Mg} \#$ & 31.77 & 32.83 & 33.28 & 31.09 & 42.10 & 34.21 & 31.77 \\
\hline $\mathrm{Sc}$ & 11.22 & 13.14 & 13.85 & 12.24 & 20.66 & 14.08 & 21.21 \\
\hline V & 85.0 & 117.6 & 123.4 & 104.0 & 128.7 & 127.7 & 194.7 \\
\hline $\mathrm{Cr}$ & 3.96 & 13.72 & 14.64 & 3.22 & 98.93 & 9.28 & 58.96 \\
\hline $\mathrm{Mn}$ & 1744 & 1773 & 1754 & 1745 & 1946 & 1824 & 1629 \\
\hline $\mathrm{Co}$ & 27.53 & 28.73 & 30.26 & 32.39 & 33.04 & 31.14 & 53.35 \\
\hline $\mathrm{Ni}$ & 2.61 & 9.44 & 10.01 & 8.35 & 65.69 & 7.24 & 87.91 \\
\hline $\mathrm{Cu}$ & 11.01 & 22.42 & 22.26 & 17.27 & 33.37 & 21.50 & 31.30 \\
\hline $\mathrm{Zn}$ & 110.5 & 111.7 & 116.4 & 124.1 & 112.4 & 111.4 & 212.8 \\
\hline $\mathrm{Ga}$ & 18.40 & 19.76 & 20.31 & 21.19 & 19.24 & 19.57 & 34.54 \\
\hline $\mathrm{Rb}$ & 48.45 & 38.91 & 30.17 & 40.35 & 36.96 & 37.79 & 34.30 \\
\hline $\mathrm{Li}$ & 9.56 & 10.22 & 10.64 & 8.66 & 5.68 & 10.03 & 10.57 \\
\hline $\mathrm{Be}$ & 2.19 & 2.15 & 2.14 & 2.03 & 1.61 & 2.08 & 3.04 \\
\hline $\mathrm{Sr}$ & 1079 & 1031 & 1031.6 & 995.9 & 913.3 & 942.0 & 787.4 \\
\hline Y & 37.80 & 34.39 & 34.94 & 35.37 & 33.72 & 34.78 & 56.51 \\
\hline $\mathrm{Zr}$ & 330.8 & 375.2 & 357.1 & 327.6 & 273.3 & 318.7 & 578.9 \\
\hline $\mathrm{Nb}$ & 85.52 & 89.12 & 87.41 & 84.90 & 77.36 & 82.99 & 68.25 \\
\hline Cs & 0.41 & 0.29 & 0.32 & 0.57 & 0.25 & 0.28 & 0.24 \\
\hline $\mathrm{Ba}$ & 730.2 & 760.5 & 713.2 & 736.2 & 1302.6 & 634.1 & 466.6 \\
\hline $\mathrm{La}$ & 56.06 & 57.22 & 55.40 & 57.22 & 58.12 & 51.91 & 55.56 \\
\hline $\mathrm{Ce}$ & 116.3 & 111.0 & 108.9 & 116.0 & 119.0 & 103.8 & 124.7 \\
\hline $\operatorname{Pr}$ & 14.38 & 13.26 & 12.94 & 14.40 & 14.80 & 12.72 & 16.70 \\
\hline $\mathrm{Nd}$ & 57.60 & 50.92 & 49.76 & 56.56 & 58.96 & 49.72 & 72.69 \\
\hline $\mathrm{Sm}$ & 11.15 & 9.49 & 9.50 & 10.78 & 11.01 & 9.33 & 16.16 \\
\hline $\mathrm{Eu}$ & 3.86 & 3.15 & 3.17 & 3.72 & 4.38 & 3.11 & 5.22 \\
\hline $\mathrm{Gd}$ & 9.91 & 8.17 & 8.24 & 9.37 & 9.67 & 8.27 & 15.30 \\
\hline $\mathrm{Tb}$ & 1.32 & 1.14 & 1.13 & 1.29 & 1.25 & 1.15 & 2.16 \\
\hline Dy & 7.03 & 6.24 & 6.16 & 6.68 & 6.63 & 6.30 & 11.20 \\
\hline Ho & 1.30 & 1.15 & 1.20 & 1.23 & 1.22 & 1.20 & 1.95 \\
\hline $\mathrm{Er}$ & 3.21 & 3.02 & 3.08 & 3.07 & 2.91 & 3.12 & 4.60 \\
\hline $\mathrm{Tm}$ & 2.31 & 2.55 & 2.71 & 2.32 & 2.45 & 2.38 & 2.68 \\
\hline $\mathrm{Yb}$ & 2.55 & 2.67 & 2.68 & 2.45 & 2.24 & 2.63 & 3.30 \\
\hline $\mathrm{Lu}$ & 0.35 & 0.38 & 0.38 & 0.34 & 0.31 & 0.38 & 0.44 \\
\hline Hf & 6.40 & 7.01 & 6.74 & 6.53 & 5.59 & 6.32 & 11.67 \\
\hline $\mathrm{Ta}$ & 4.51 & 4.84 & 4.36 & 3.87 & 4.20 & 3.62 & 3.63 \\
\hline W & 0.45 & 0.69 & 0.40 & 0.96 & 0.43 & 0.29 & 0.92 \\
\hline $\mathrm{Pb}$ & 2.94 & 3.57 & 3.42 & 3.16 & 2.30 & 3.38 & 3.18 \\
\hline Th & 5.04 & 5.16 & 4.94 & 5.24 & 4.66 & 4.70 & 4.86 \\
\hline $\mathrm{U}$ & 1.32 & 1.33 & 1.29 & 1.39 & 1.22 & 1.24 & 1.41 \\
\hline
\end{tabular}




\begin{tabular}{|c|c|c|c|}
\hline Latitude: & N05¹2'33.6" & N0506'07.3" & N05 $09^{\prime} 49.3^{\prime \prime}$ \\
\hline Longitude: & $\mathrm{E} 10^{\circ} 10^{\prime} 15.2^{\prime \prime}$ & E1009'10.6" & $\mathrm{E} 10^{\circ} 09^{\prime} 58.3^{\prime \prime}$ \\
\hline Rocks type & Mugearites & & \\
\hline Samples & BAF 3 & BAF 37 & BAF 41 \\
\hline $\mathrm{SiO}_{2}$ & 48.97 & 51.53 & 49.34 \\
\hline $\mathrm{TiO}_{2}$ & 2.09 & 1.39 & 2.15 \\
\hline $\mathrm{Al}_{2} \mathrm{O}_{3}$ & 16.19 & 16.25 & 16.39 \\
\hline $\mathrm{Fe}_{2} \mathrm{O}_{3} \mathrm{t}$ & 13.28 & 12.66 & 13.09 \\
\hline $\mathrm{MnO}$ & 0.24 & 0.25 & 0.22 \\
\hline $\mathrm{MgO}$ & 3.25 & 2.38 & 3.45 \\
\hline $\mathrm{CaO}$ & 5.29 & 4.14 & 5.41 \\
\hline $\mathrm{Na}_{2} \mathrm{O}$ & 4.60 & 5.17 & 4.40 \\
\hline $\mathrm{K}_{2} \mathrm{O}$ & 2.13 & 2.46 & 2.07 \\
\hline $\mathrm{P}_{2} \mathrm{O}_{5}$ & 1.20 & 1.17 & 1.18 \\
\hline LOI & 1.88 & 1.89 & 1.56 \\
\hline TOTAL & 99.12 & 99.28 & 99.25 \\
\hline $\mathrm{Mg \#}$ & 29.17 & 24.01 & 30.73 \\
\hline $\mathrm{Sc}$ & 10.02 & 6.65 & 9.79 \\
\hline V & 51.68 & 8.67 & 56.79 \\
\hline $\mathrm{Cr}$ & 4.81 & 1.76 & 1.60 \\
\hline $\mathrm{Mn}$ & 1825 & 1924 & 1692 \\
\hline Co & 23.13 & 15.56 & 24.43 \\
\hline $\mathrm{Ni}$ & 1.71 & 0.37 & 1.13 \\
\hline $\mathrm{Cu}$ & 9.67 & 5.99 & 10.18 \\
\hline $\mathrm{Zn}$ & n.a & n.a & 117.1 \\
\hline $\mathrm{Ga}$ & 68.18 & 72.56 & 18.96 \\
\hline $\mathrm{Rb}$ & 34.28 & 51.37 & 32.90 \\
\hline $\mathrm{Li}$ & 9.78 & 9.50 & 8.54 \\
\hline $\mathrm{Be}$ & 1.90 & 2.21 & 2.08 \\
\hline $\mathrm{Sr}$ & 1056 & 1115 & 1387 \\
\hline $\mathrm{Y}$ & 40.96 & 42.72 & 39.89 \\
\hline $\mathrm{Zr}$ & 385.2 & 461.7 & 353.6 \\
\hline $\mathrm{Nb}$ & 97.63 & 121.6 & 90.22 \\
\hline $\mathrm{Cs}$ & 0.42 & 0.41 & 0.10 \\
\hline $\mathrm{Ba}$ & 840.7 & 884.7 & 893.3 \\
\hline $\mathrm{La}$ & 65.73 & 76.99 & 61.26 \\
\hline $\mathrm{Ce}$ & 128.0 & 146.0 & 125.8 \\
\hline $\operatorname{Pr}$ & 16.51 & 18.86 & 15.62 \\
\hline $\mathrm{Nd}$ & 67.15 & 74.18 & 63.07 \\
\hline $\mathrm{Sm}$ & 12.84 & 13.66 & 11.97 \\
\hline $\mathrm{Eu}$ & 4.45 & 4.54 & 4.22 \\
\hline Gd & 10.03 & 10.17 & 10.53 \\
\hline $\mathrm{Tb}$ & 1.41 & 1.45 & 1.40 \\
\hline Dy & 7.72 & 7.92 & 7.49 \\
\hline Ho & 1.41 & 1.47 & 1.38 \\
\hline $\mathrm{Er}$ & 3.59 & 3.76 & 3.42 \\
\hline $\mathrm{Tm}$ & 0.00 & 0.00 & 2.60 \\
\hline $\mathrm{Yb}$ & 2.87 & 3.13 & 2.69 \\
\hline $\mathrm{Lu}$ & 0.39 & 0.45 & 0.39 \\
\hline Hf & 7.38 & 8.83 & 7.10 \\
\hline $\mathrm{Ta}$ & 4.58 & 5.25 & 5.02 \\
\hline W & 0.47 & 0.55 & 0.11 \\
\hline $\mathrm{Pb}$ & 3.67 & 4.22 & 3.29 \\
\hline $\mathrm{Th}$ & 5.50 & 6.75 & 5.54 \\
\hline $\mathrm{U}$ & 1.54 & 1.92 & 1.46 \\
\hline
\end{tabular}


Table 2. $\mathrm{K}-\mathrm{Ar}$ ages of Bafang mafic lavas.

${ }^{40} \mathrm{Ar} *$ is radiogenic argon, and $\mathrm{Ar}_{\mathrm{T}}$ is total ${ }^{40} \mathrm{Ar}$, ie radiogenic and atmospheric.

Ages are calculated using the constants proposed by Steiger and Jäger (1978).

Errors are calculated at \pm 1 sigma using the calculations by Cox and Dalrymple (1967).

\begin{tabular}{|c|c|c|c|c|c|c|c|}
\hline Sample & Rock & $\mathrm{K}_{2} \mathrm{O}(\mathrm{wt} \%)$ & $\begin{array}{c}{ }^{40} \mathrm{Ar}^{*} \\
\left(10^{-7} \mathrm{~cm}^{3} / \mathrm{g}\right)\end{array}$ & $\begin{array}{c}{ }^{40} \mathrm{Ar}^{*}{ }^{40} \mathrm{Ar}_{\mathrm{T}} \\
(\%)\end{array}$ & $\begin{array}{l}{ }^{36} \mathrm{Ar} \text { exp. } \\
\left(10^{-9} \mathrm{~cm}^{3}\right)\end{array}$ & Age (Ma) & $\begin{array}{c}\text { Internal } \\
\text { analytical } \\
\text { error } \\
( \pm 1 \text { sigma }) \\
\end{array}$ \\
\hline BAF3 & Mugearite & 2.05 & 4.563 & 51 & 0.742 & 6.89 & \pm 0.18 \\
\hline BAF18 & Basalt & 1.31 & 2.653 & 45.3 & 0542 & 6.27 & \pm 0.17 \\
\hline BAF34 & Basanite & 1.54 & 4.764 & 70.2 & 0.342 & 9.57 & \pm 0.23 \\
\hline BAF36 & Basalt & 1.33 & 2.769 & 41.3 & 1.165 & 6.45 & \pm 0.18 \\
\hline BAF36 & & 1.33 & 2.989 & & 0.885 & 6.96 & \pm 0.21 \\
\hline BAF 37 & Mugearite & 2.36 & 6.462 & 35.6 & 1.976 & 8.47 & \pm 0.26 \\
\hline BAF45 & Basanite & 1.25 & & 62.6 & 0.427 & 10.46 & \pm 0.25 \\
\hline
\end{tabular}


Table 3: $\mathrm{Sr}, \mathrm{Nd}, \mathrm{Hf}$ and $\mathrm{Pb}$ isotopic data for the Bafang la vas.

\begin{tabular}{|c|c|c|c|c|c|c|c|c|c|}
\hline Sample & ${ }^{86} \mathrm{Sr} /{ }^{87} \mathrm{Sr}$ & $1 \sigma$ & ${ }^{143} \mathrm{Nd} /{ }^{144} \mathrm{Nd}$ & $1 \sigma$ & ${ }^{176} \mathrm{Hf} /{ }^{177} \mathrm{Hf}$ & $1 \sigma$ & ${ }^{206} \mathrm{~Pb} /{ }^{204} \mathrm{~Pb}$ & ${ }^{207} \mathrm{~Pb} /{ }^{204} \mathrm{~Pb}$ & ${ }^{208} \mathrm{~Pb} /{ }^{204} \mathrm{~Pb}$ \\
\hline BAF 2 & 0.704119 & 3 & 0.512840 & 4 & 0.282890 & 2 & 19.862 & 15.645 & 39.681 \\
\hline BAF 3 & 0.703236 & 4 & 0.512833 & 4 & 0.282876 & 3 & 19.845 & 15.642 & 39.642 \\
\hline BAF 10 & 0.704173 & 3 & 0.512812 & 4 & 0.282875 & 2 & 19.037 & 15.540 & 38.652 \\
\hline BAF 15 & 0.704118 & 4 & 0.512880 & 4 & 0.282896 & 2 & 19.459 & 15.624 & 39.320 \\
\hline BAF 18 & 0.704120 & 3 & 0.512881 & 3 & 0.282890 & 3 & 19.290 & 15.633 & 39.257 \\
\hline BAF 22 & 0.703241 & 4 & 0.512939 & 4 & 0.282935 & 3 & 20.033 & 15.664 & 39.700 \\
\hline BAF 34 & 0.703350 & 4 & 0.512909 & 6 & 0.282908 & 2 & 20.054 & 15.663 & 39.871 \\
\hline BAF 36 & 0.703488 & 4 & 0.512911 & 3 & 0.282937 & 3 & 20.072 & 15.638 & 39.640 \\
\hline BAF 37 & 0.703857 & 4 & 0.512863 & 4 & 0.282885 & 2 & 19.846 & 15.648 & 39.596 \\
\hline BAF 42 & 0.703345 & 5 & 0.512879 & 8 & 0.282913 & 3 & 19.885 & 15.653 & 39.587 \\
\hline BAF 43 & 0.704101 & 4 & 0.512883 & 5 & 0.282902 & 2 & 19.497 & 15.633 & 39.359 \\
\hline BAF 44 & 0.703304 & 4 & 0.512904 & 6 & 0.282928 & 2 & 19.913 & 15.648 & 39.591 \\
\hline BAF 45 & 0.703123 & 4 & 0.512900 & 200 & 0.282910 & 3 & 20.048 & 15.666 & 39.625 \\
\hline
\end{tabular}




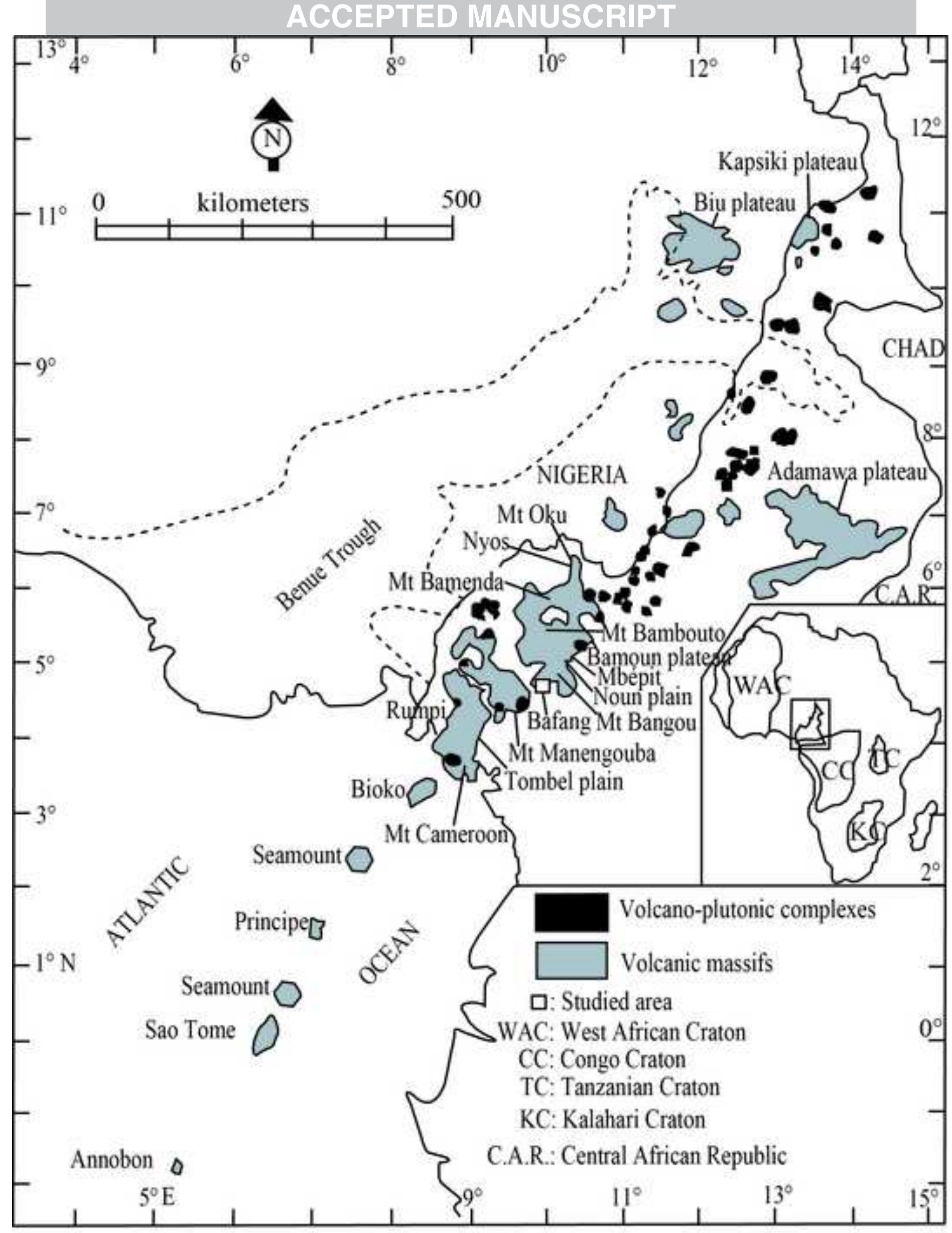

Fig. 1 


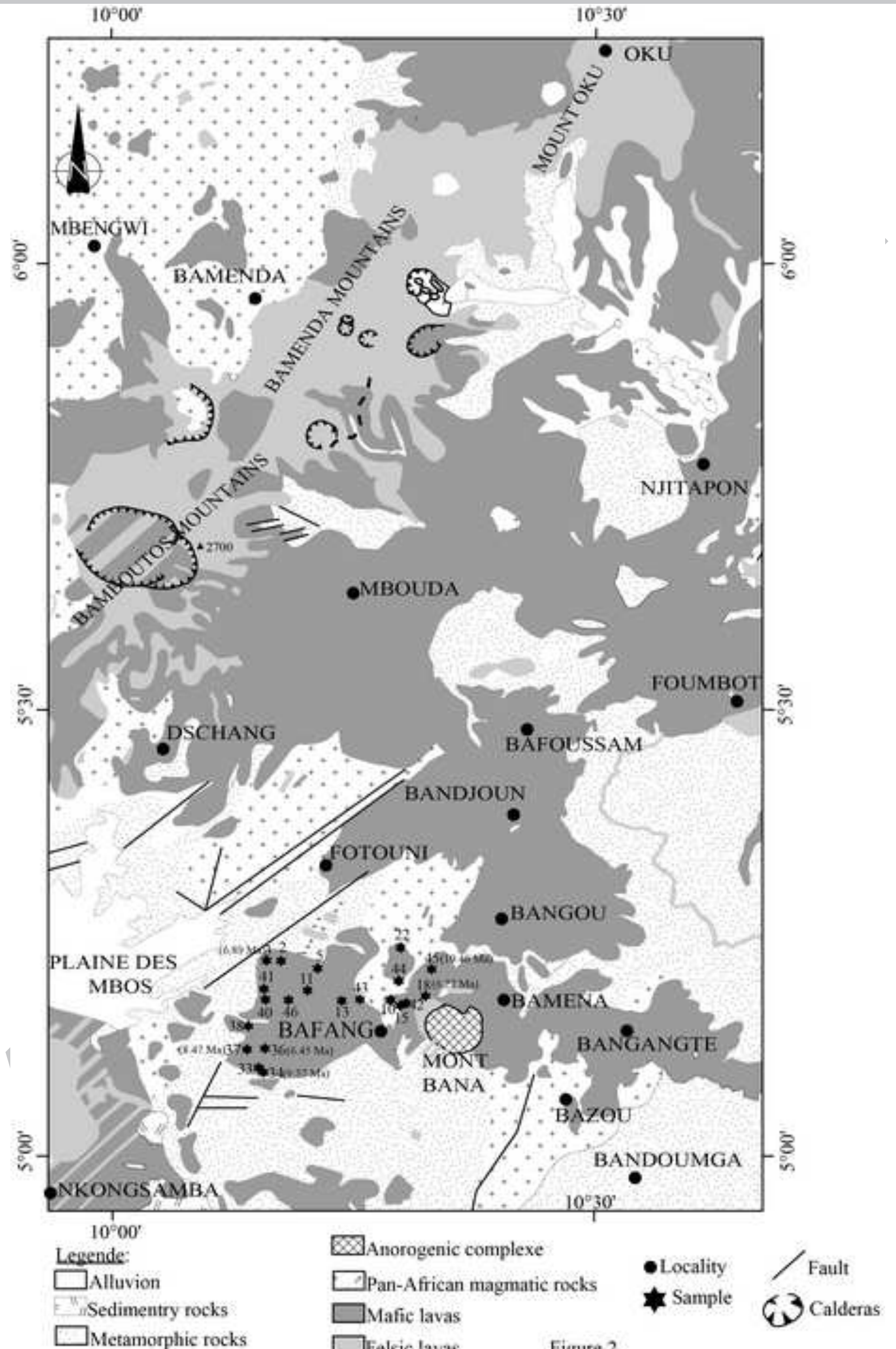

ACCEPTED MANUSCRIPT

$1 \mathrm{OKU}$

Figure 2 


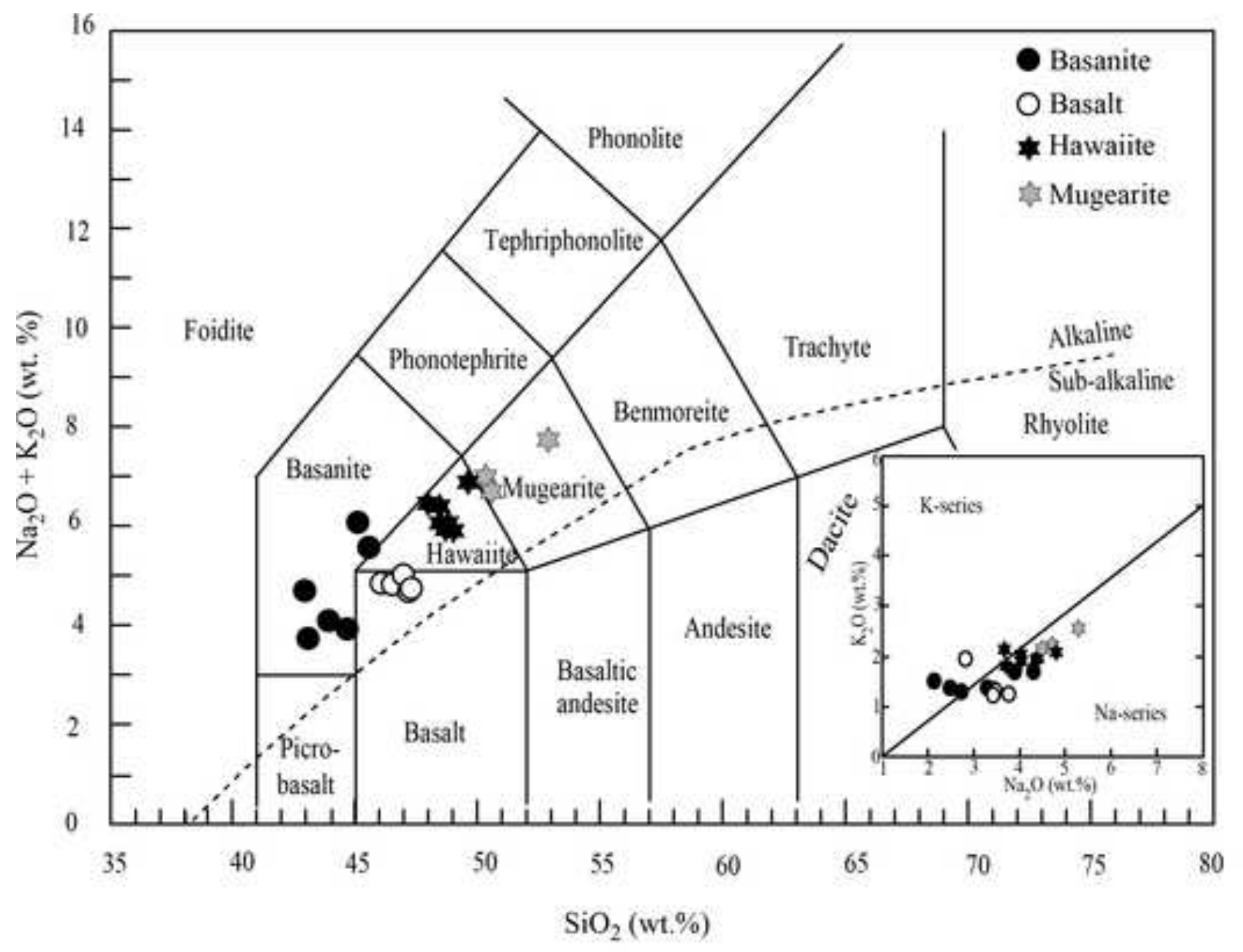

Figure 3 

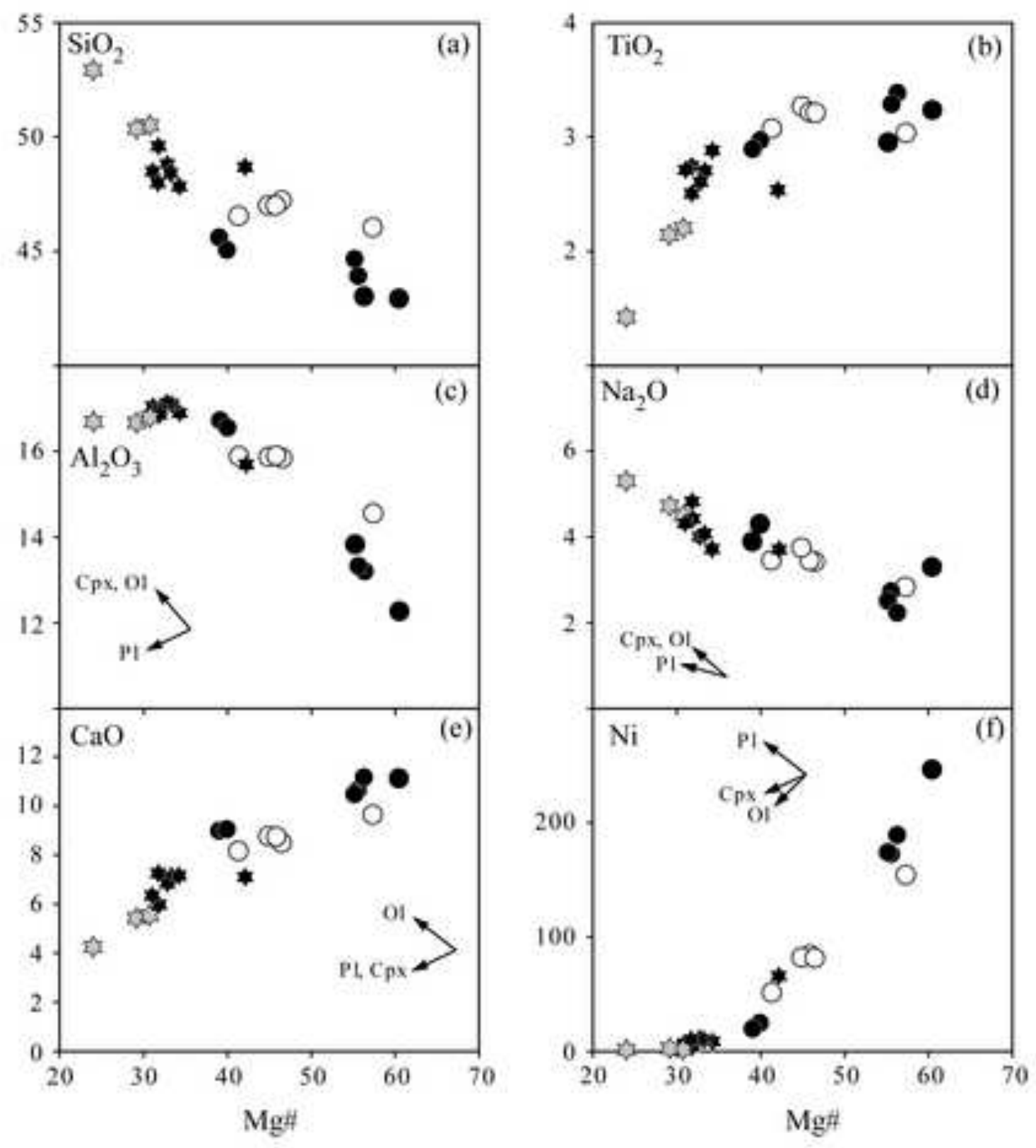

Figure 4 

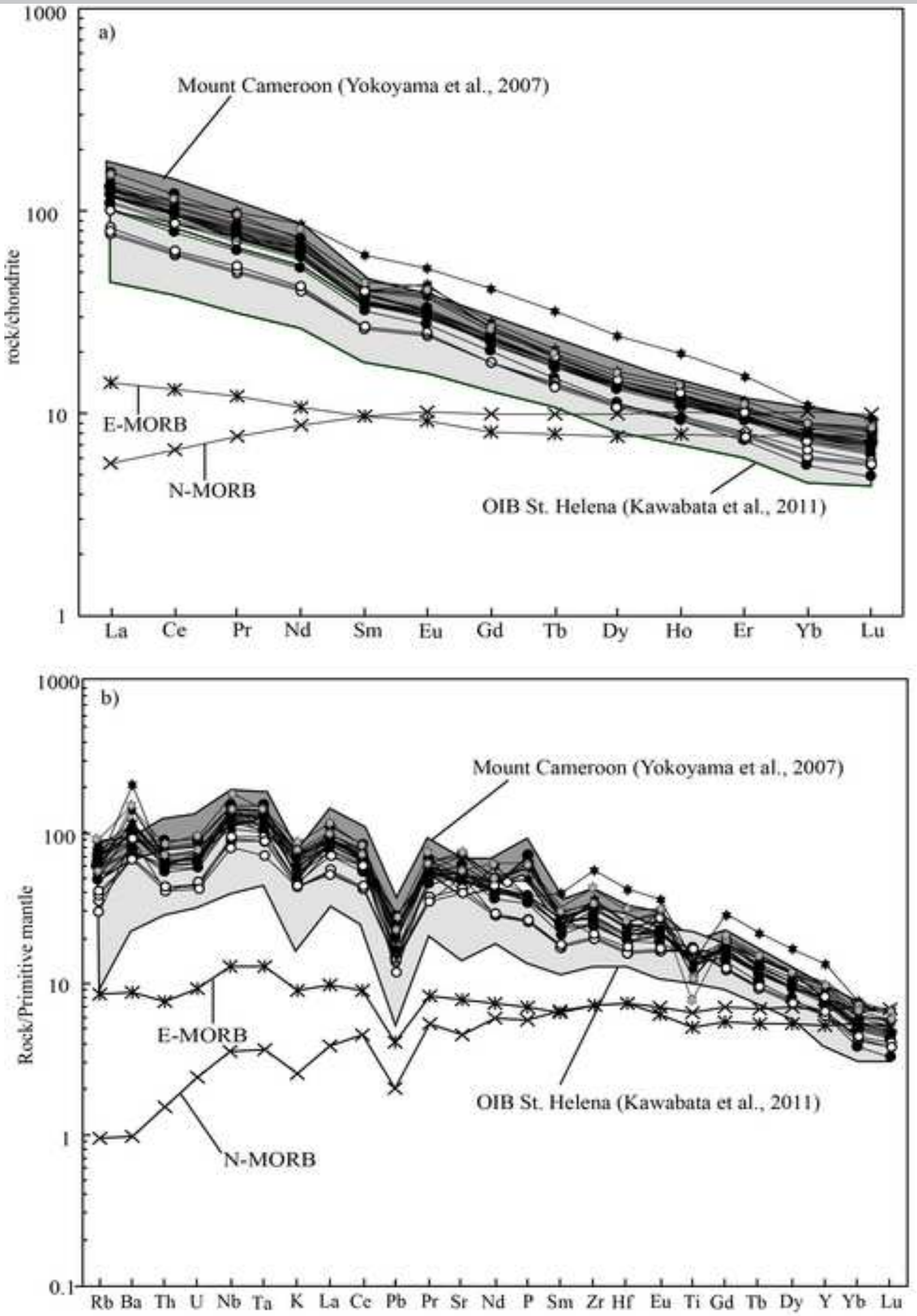

Fig 5 

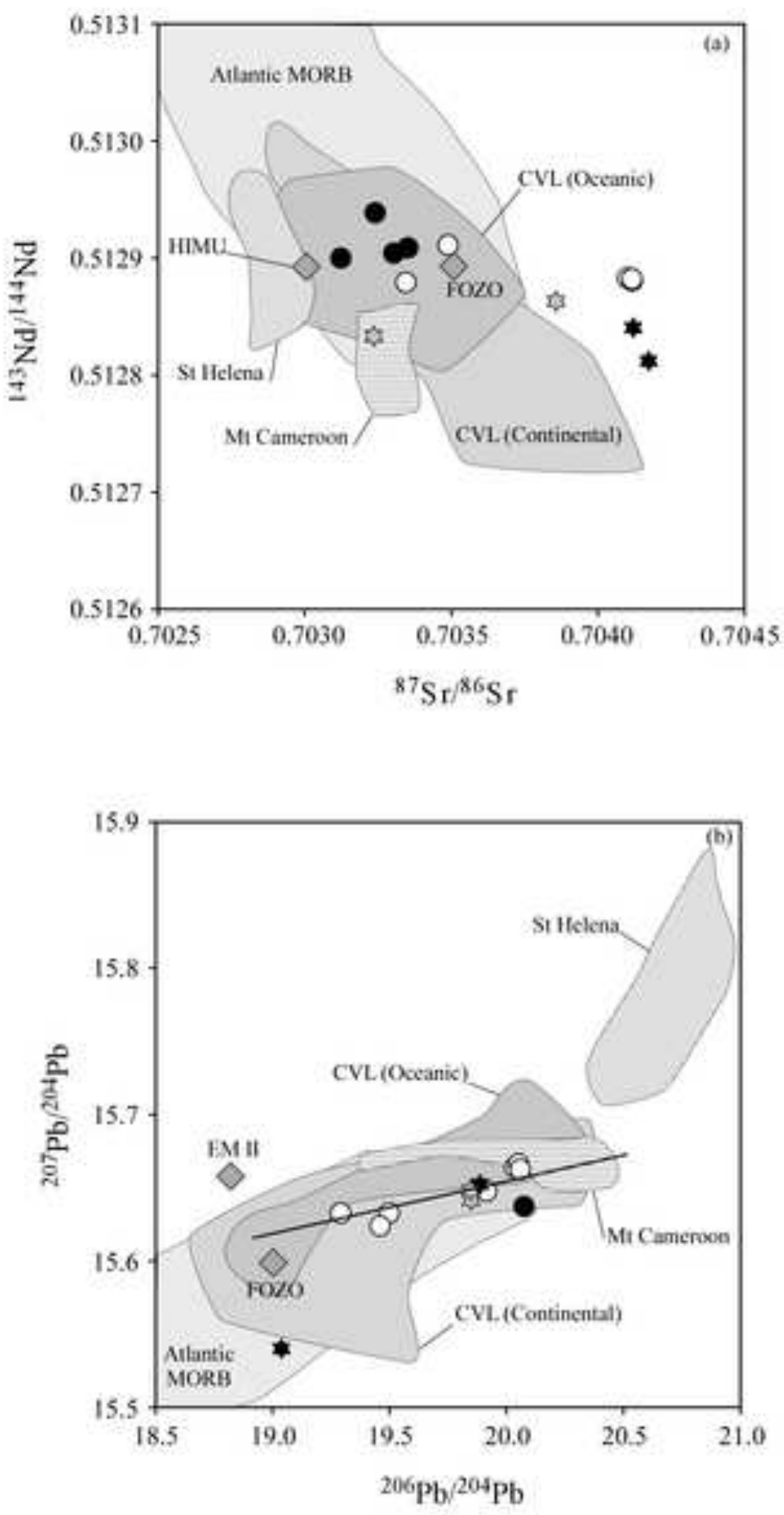

Figure 6 
Figure

Figure
\[ A C C E P T E D \text { MANUSCRIPT } \]

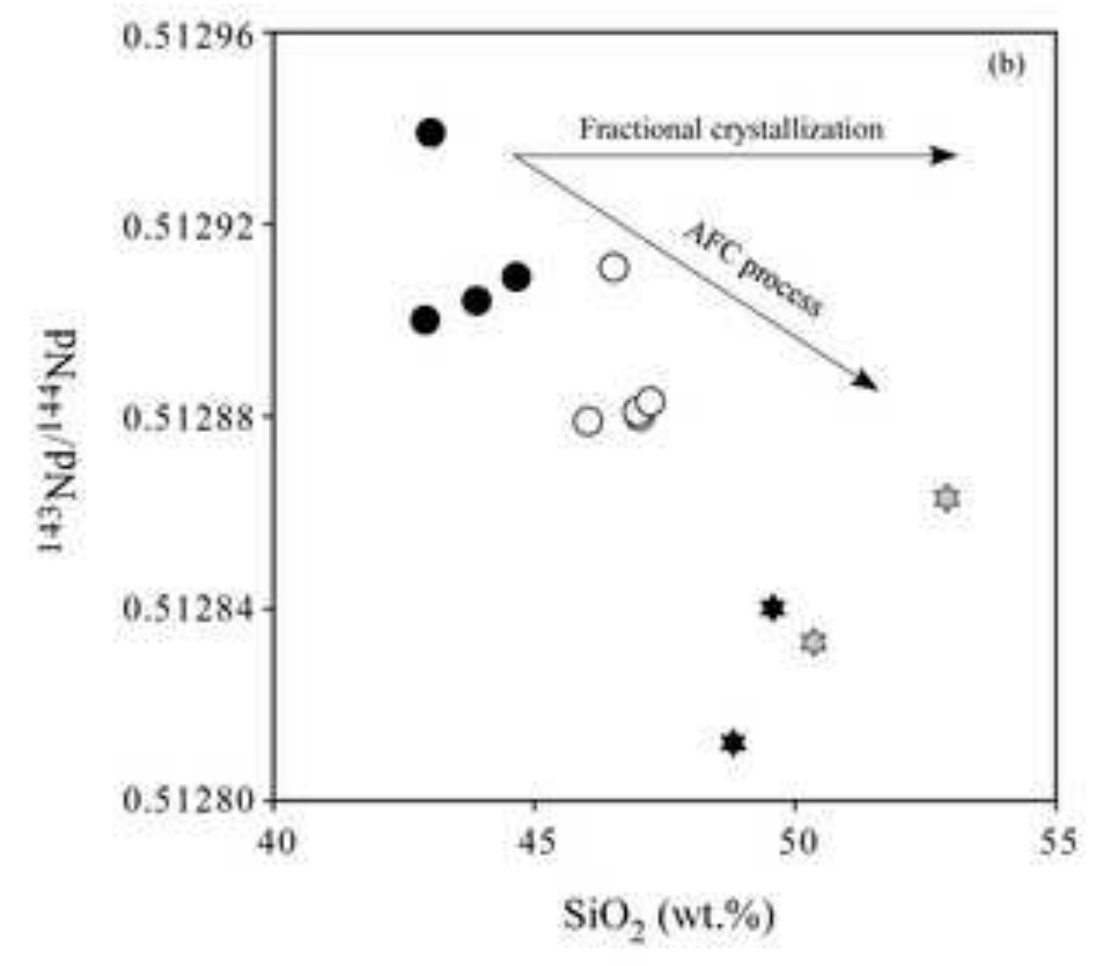

Figure 7

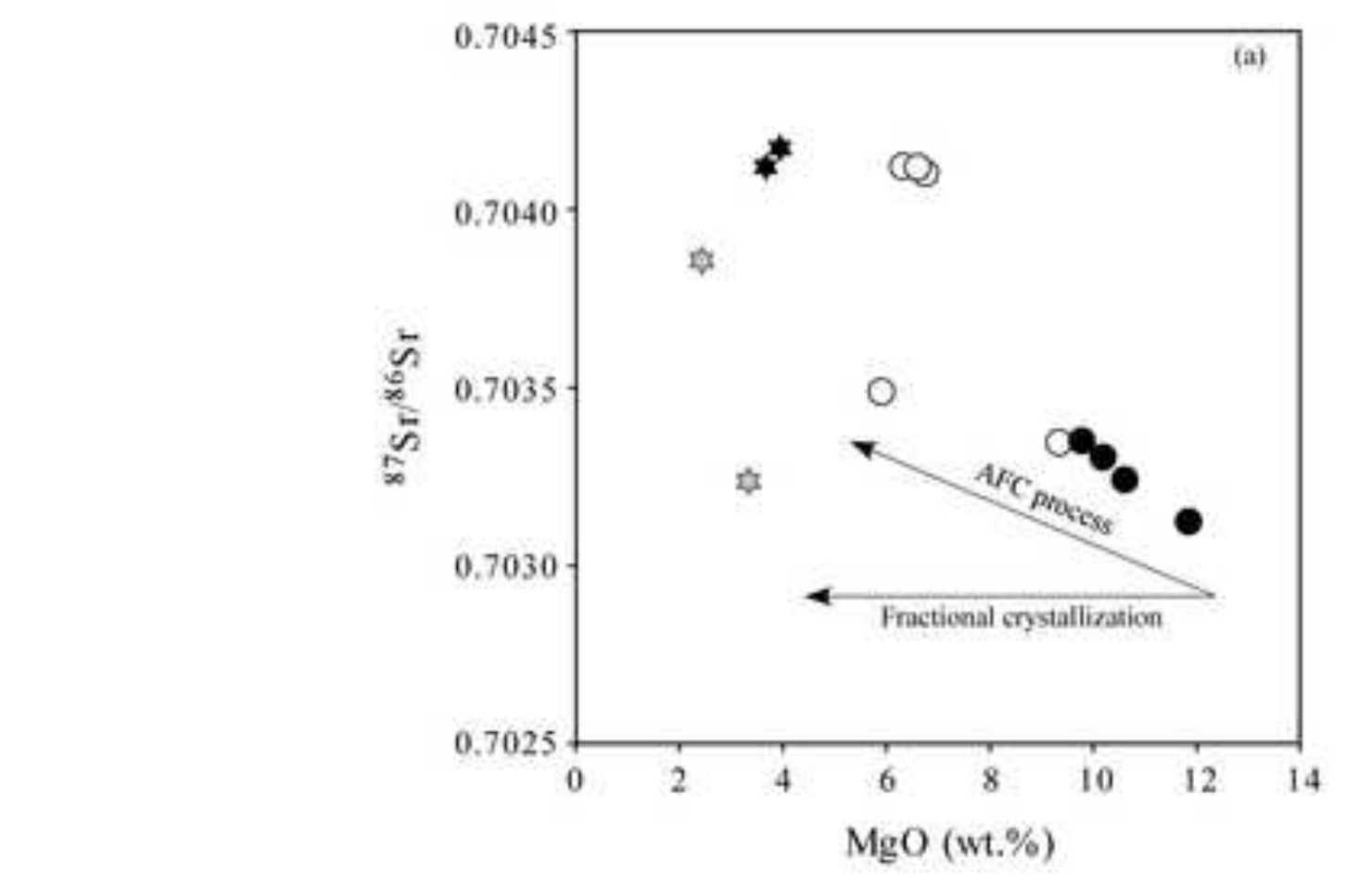

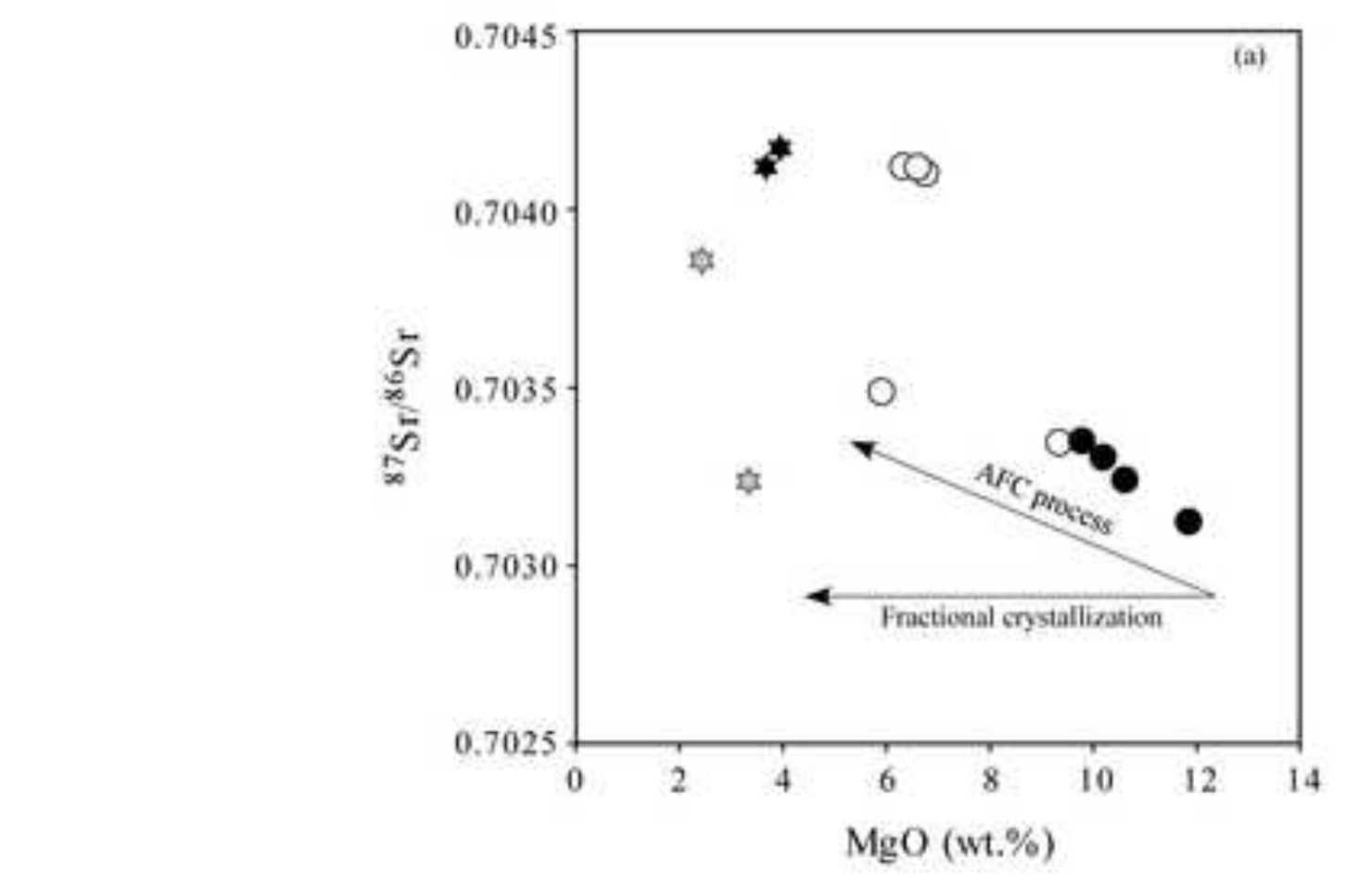
(14) -

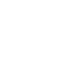

.

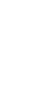

\section{Figure 7}
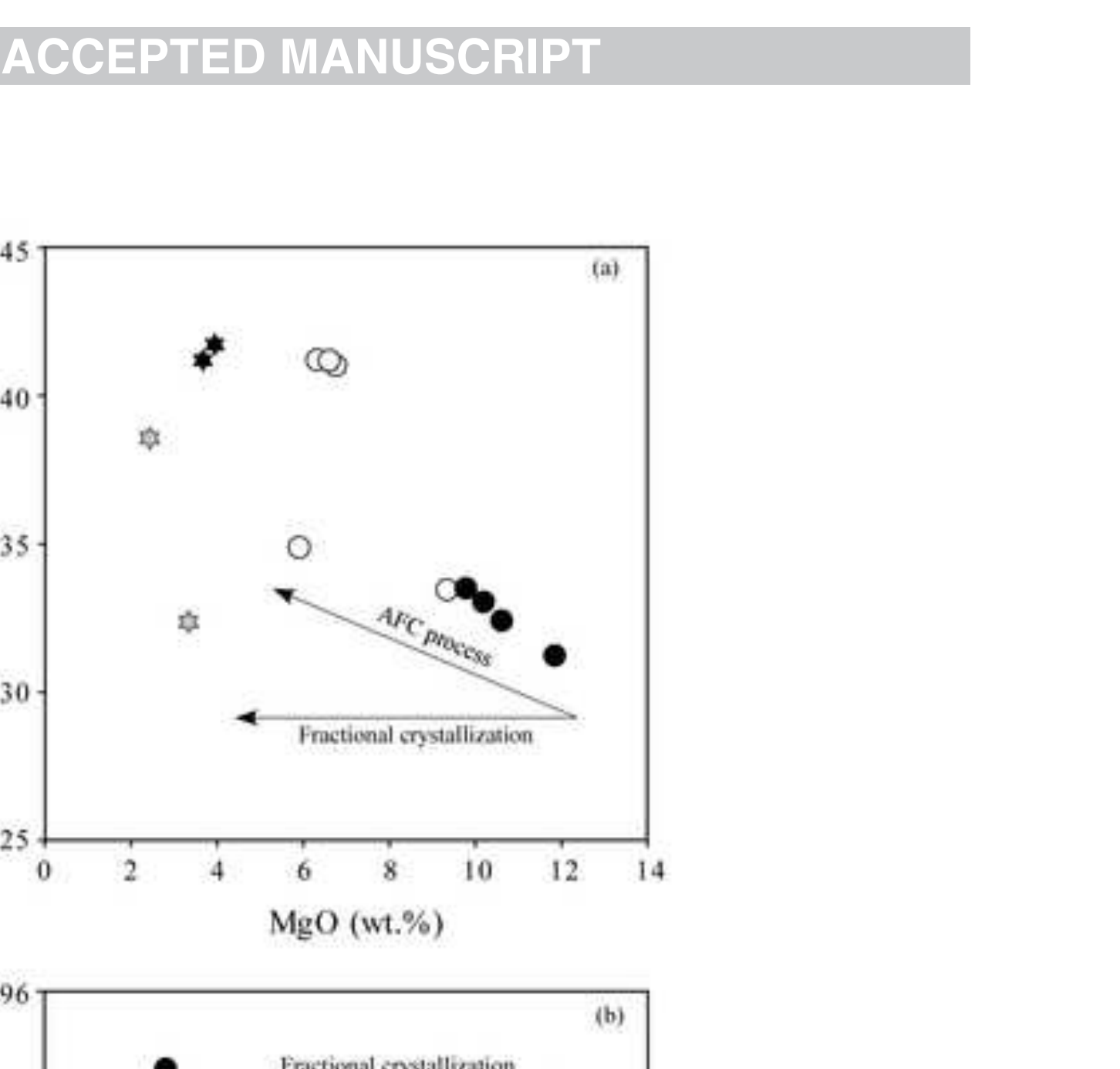

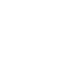
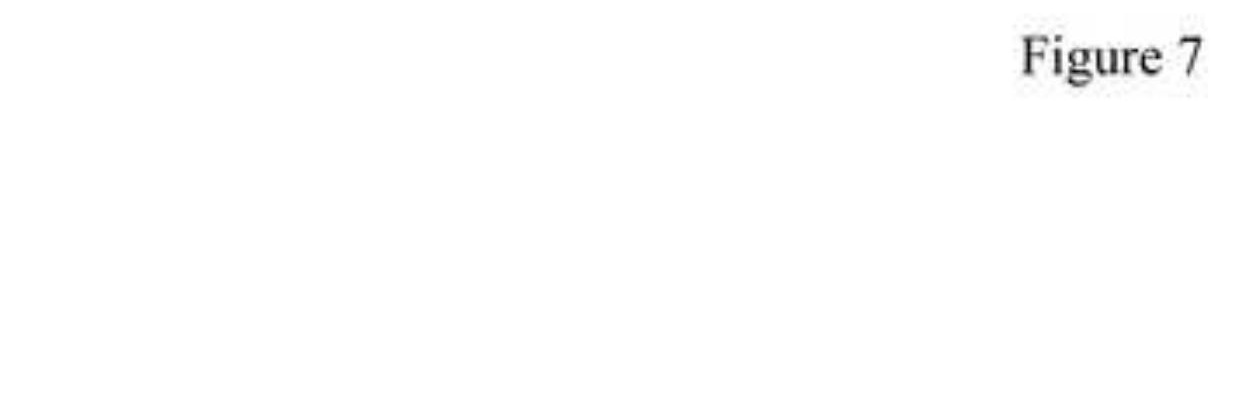


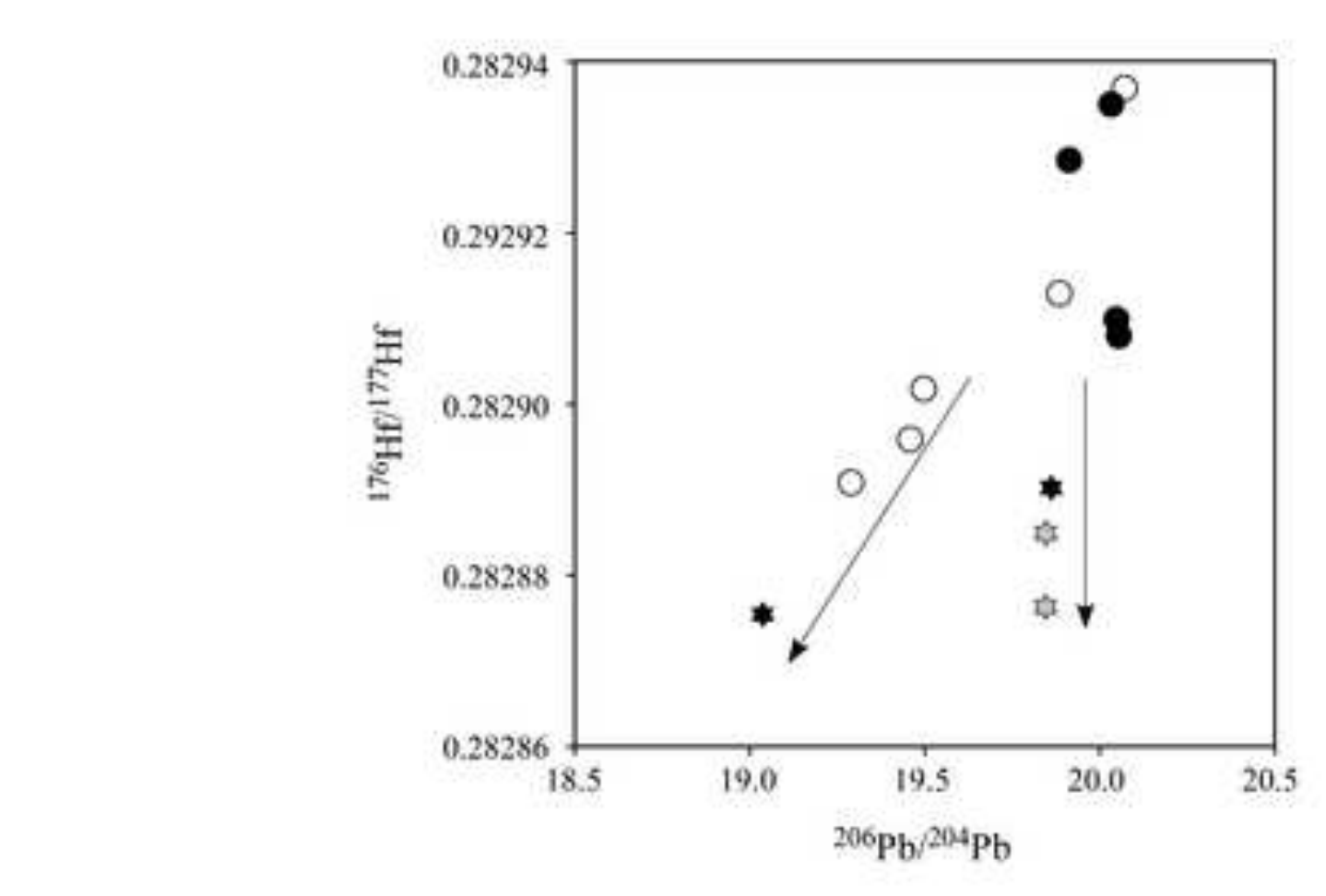

Figure 8

Figure

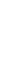

\section{(2)

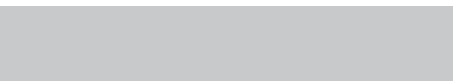

\section{Fisire 8}

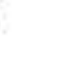

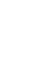

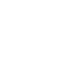

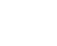
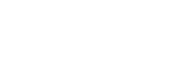

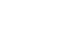

.

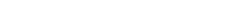

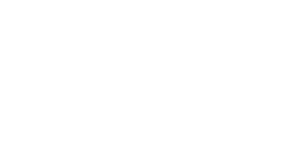

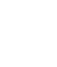

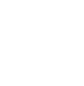

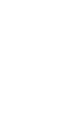

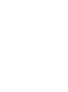

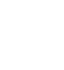

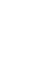

Cas
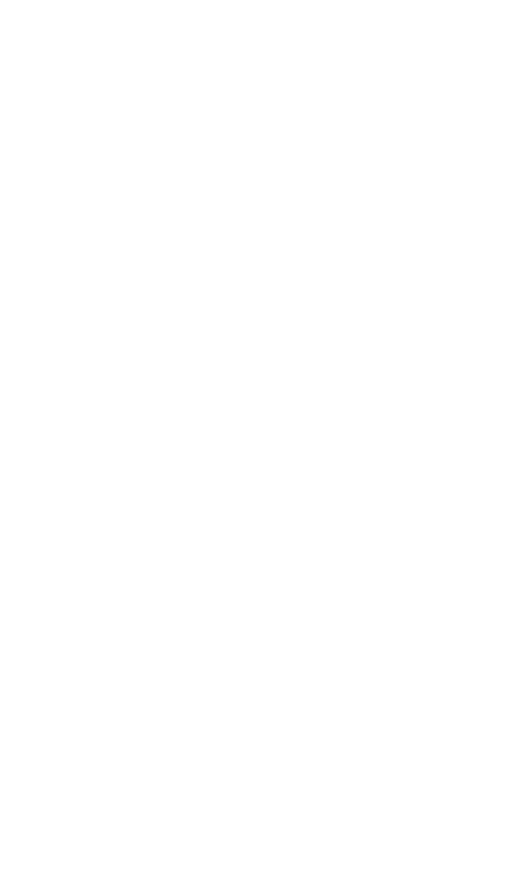


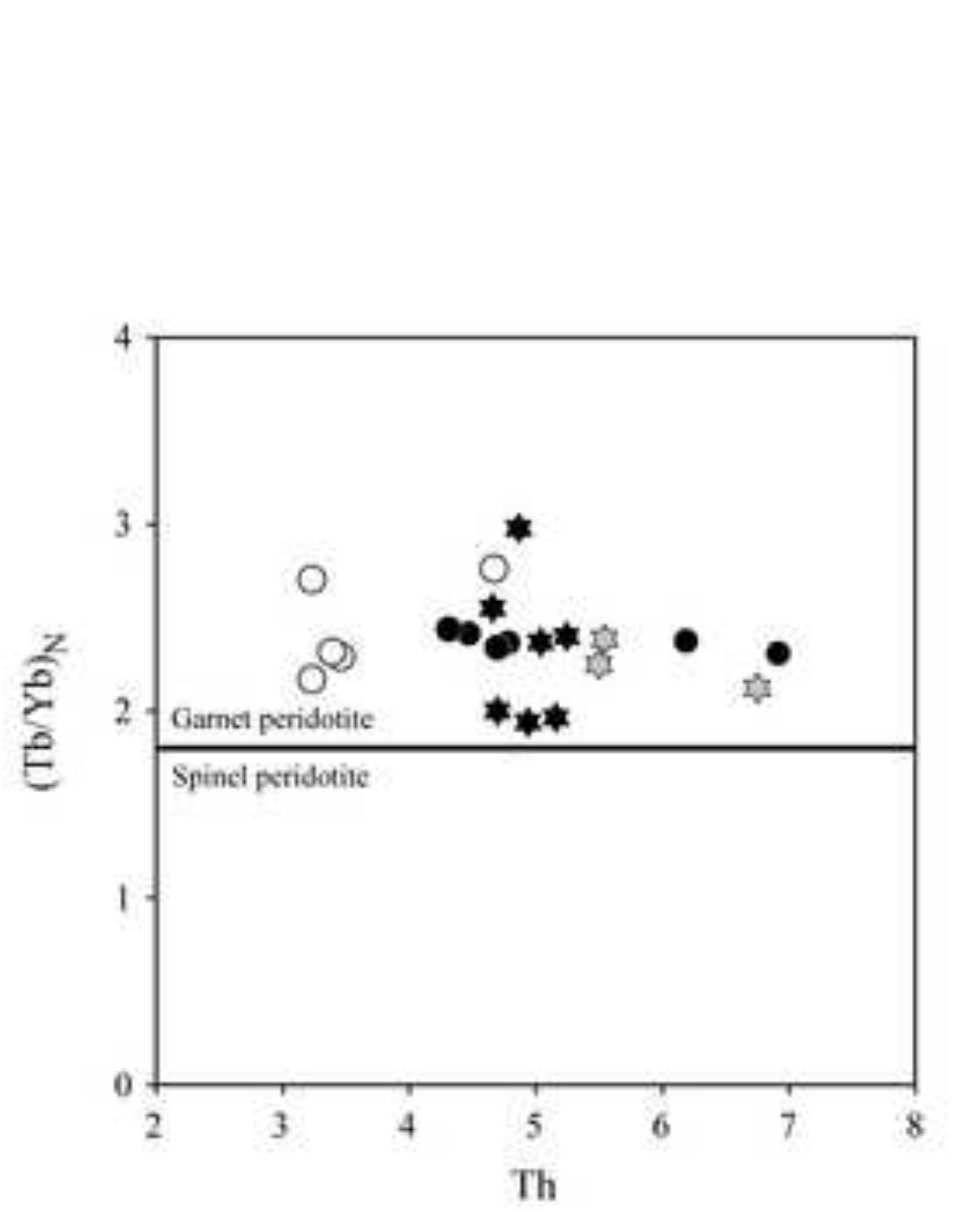

Figure 9

Figure

ACGEPTED MANUSGRIPT

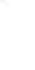

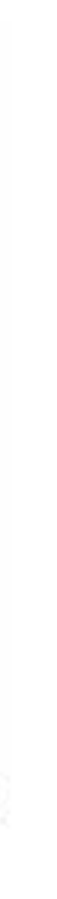

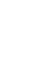

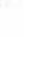

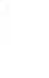

.

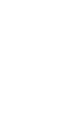

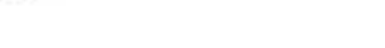

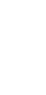

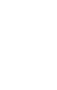

(1)

(1)

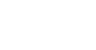
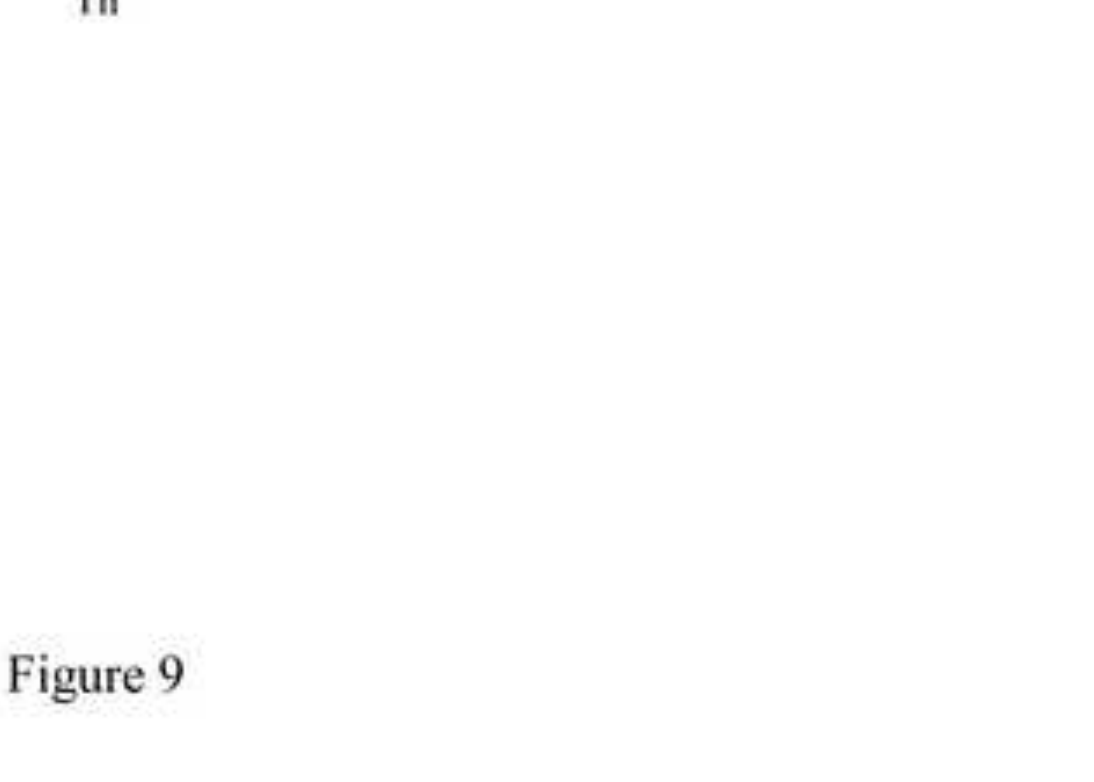
Figure

\section{ACCEPTED MANUSCRIPT}
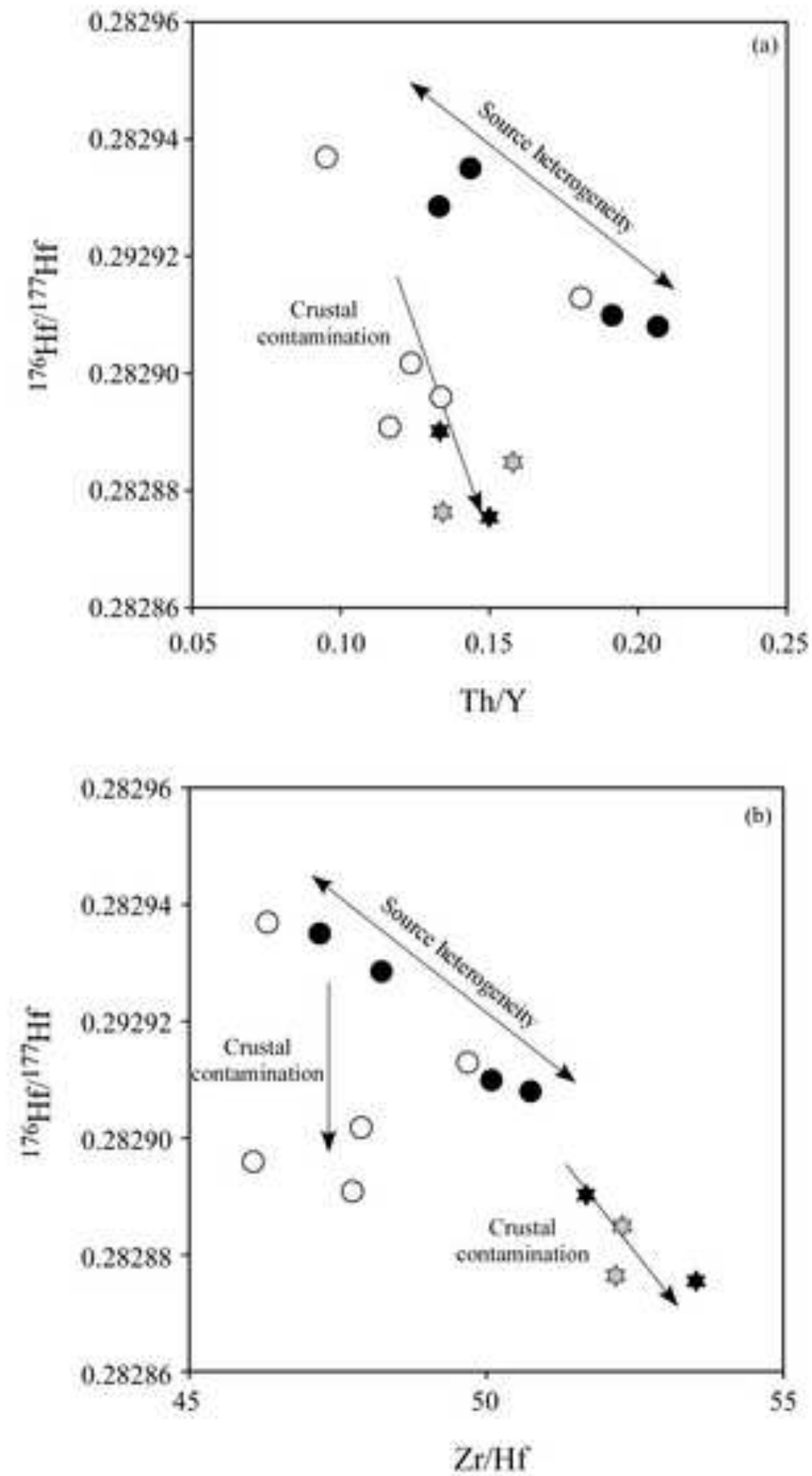

Figure 10 

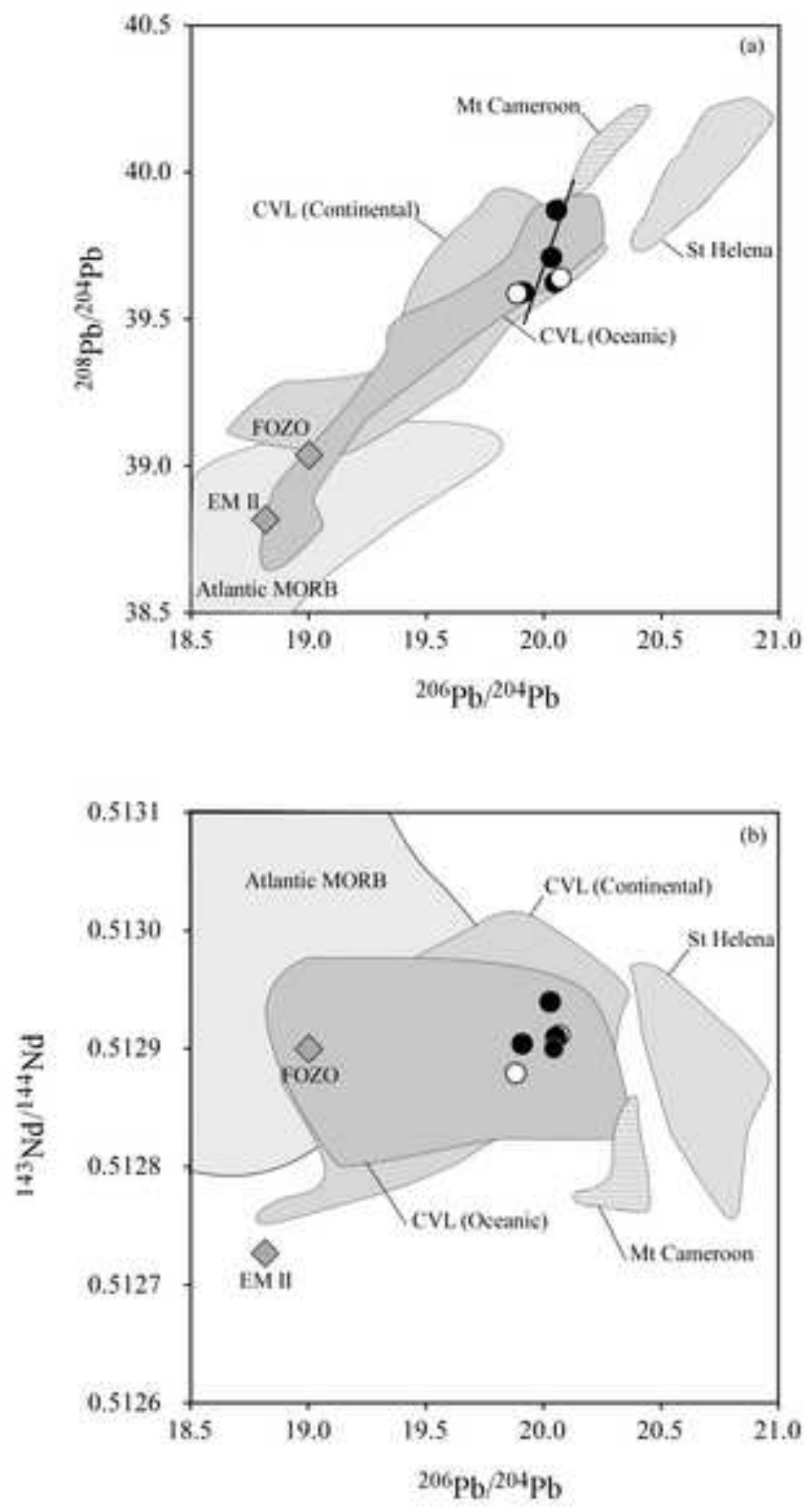

Figure 11 